\section{Estudo \\ CoDebate}

em Cestão

Planejamento
Revista Estudo \& Debate, Lajeado, v. 24, n. 3, 2017. ISSN 1983-036X

DOI: http://dx.doi.org/10.22410/issn.1983-036X.v24i3a2017.1333

\title{
ESTIMATIVA DA EROSÃO LAMINAR NA BACIA HIDROGRÁFICA DO RIBEIRÁO JOÁO LEITE - GO A PARTIR DE ANÁLISE ESPACIAL DE DADOS
}

\author{
Elaine Eluizy Ribeiro Silva ${ }^{1}$, Estéfane Silva Lopes ${ }^{2}$, Luana Regina Pires de Sousa ${ }^{3}$, \\ Marina Alberti Macedo ${ }^{4}$, Cecília de Castro Bolina ${ }^{5}$, Marcelus Isaac Lemos Gomes ${ }^{6}$
}

\begin{abstract}
Resumo: No ano de 2009 foi construída a barragem do Ribeirão João Leite, localizada na região central do Estado de Goiás, obra que garante parte do abastecimento de água da população de Goiânia-GO e região metropolitana por 25 anos. A tendência de crescimento populacional a ser atendida por esta barragem indica a necessidade de preservação da qualidade da água distribuída a seus consumidores. Baseado neste fato, o presente estudo tem o objetivo de quantificar a perda de solos por erosão laminar na bacia hidrográfica do Ribeirão João Leite, no ano de 2011 para verificar o potencial de erosão no manancial. A perda de solo foi estimada de forma quantitativa por meio da Equação Universal de Perda de Solos, utilizando para tanto, um Sistema de Informações Geográficas ArcGis 9.3 para processamento, tratamento e produção de informações. O cálculo feito através desta Equaçáo foi realizado por meio da inclusão de um algoritmo para o cálculo automatizado dos fatores topográfico, de potencial natural à erosão laminar, de perda de solo por erosão laminar, e comprimento de rampa. O Sistema de Informaçóes Geográficas se mostrou altamente eficiente no sentido de possibilitar a obtenção de informaçóes macros de forma rápida. $\mathrm{O}$ resultado obtido mostrou que $74,01 \%$ da área da bacia possuem fraco potencial e $25,99 \%$ da área da bacia possui moderado a forte potencial a erosão, necessitando assim, de práticas conservacionistas para evitar erosôes mais acentuadas.
\end{abstract}

Palavras-chave: Perda de solos. Erosão. Sistema de informaçóes geográficas.

1 Engenheira Civil e Agrimensora - IFG Goiânia, e-mail: elaineeluizy@gmail.com

2 Engenheira Civil e Agrimensora - IFG Goiânia, e-mail: cecigirlbr@yahoo.com.br

3 Engenheira Civil e Agrimensora - IFG Goiânia, e-mail: luanaengenharia@hotmail.com

4 Professora Instituto Federal de Goiás, marina_alberti @hotmail.com

5 Professora da Universidade Federal de Goiás - Regional Jataí, e-mail: ceciliabolina@bol.com.br

6 Engenheiro da Universidade Federal de Goiás e Professor da Pontifícia Universidade Católica de Goiás, e-mail: marcelusisaac@uol.com.br 


\title{
GEOGRAPHICAL INFORMATION SYSTEM: ESTIMATION OF LAMINAR EROSION IN THE HYDROGRAPHIC RIBEIRÃO JOÃO LEITE - GO
}

\begin{abstract}
In 2009, the Ribeirão João Leite dam, located in the central region of the State of Goiás, was built, guaranteeing part of the water supply of the population of Goiania-GO and metropolitan region for twentyfive (25) years. The trend of population growth to be met by this dam indicates the need to preserve the quality of the water distributed to its consumers. Based on this fact, the present work has the objective of quantifying the loss of soils by laminar erosion in the watershed of Ribeirão João Leite, in the current period of the present work, to verify the potential of erosion in the spring. The soil loss was quantitatively estimated through the Universal Soil Loss Equation, using an ArcGIS 9.3 Geographic Information System for processing, treatment and production of information. The calculation made by this equation included the inclusion of an algorithm for automated calculation of topographic factors, natural potential to laminar erosion, soil loss by laminar erosion, and ramp length. The Geographic Information System proved to be highly efficient in order to obtain macro information quickly. The results showed that $74.01 \%$ of the basin area has a weak potential and $25.99 \%$ of the basin area has moderate to strong erosion potential, thus requiring conservation practices to avoid more severe erosion.
\end{abstract}

Keywords: Loss of Soil. Erosion. Geographic information system.

\section{INTRODUÇÃO}

O desencadeamento de fatores naturais e antrópicos, intensificado pelo acelerado crescimento populacional e expansão urbana desordenada, coloca no cerne dos problemas globais de degradação ambiental a perda de solos por erosão laminar.

A ocupação do solo, ausente de planejamento, provoca fatores que contribuem para o risco de erosão, entre eles o excesso de superfícies sem cobertura vegetal, que reduzem a taxa de infiltração de águas das chuvas, produzindo a intensificação dos riscos de erosão, deslizamentos, compactação dos solos e alagamento de córregos e ruas (MOURA et al., 2017).

A erosão laminar é a remoção de camadas finas do solo superficial - é a forma de erosấo menos notada - e por isso a mais perigosa. Nos dias de precipitação intensa as enxurradas tomam aspecto barrento. Os solos, por sua vez, tomam coloração mais clara, e a produtividade e fertilidade na região afetada tem queda progressiva (NUNES et al., 2013; PASQUATTO; TOMAZONI, 2016).

A Bacia Hidrográfica do Ribeirão João Leite, situada no Estado de Goiás é responsável por parte do abastecimento de água do Município de Goiânia e região metropolitana.

A estimativa da perda de solos por erosão laminar pode ser realizada por métodos quantitativos ou qualitativos. Os métodos qualitativos possuem como vantagem a facilidade de manipulação dos fatores selecionados em termos de grau de risco a erosão e sua posterior combinação para a obtenção dos graus de severidade erosiva e por desvantagem o fato de não obter valores numéricos, importantes para a estimativa de degradação e sedimentação do solo. Os métodos quantitativos de perda de solos permitem a estimativa da erosáo de forma mais precisa, facilitando a realização, na área de estudo, de um projeto de caráter conservacionista. Os modelos quantitativos exigem conhecimento por parte do usuário 
e mais informaçóes do que os modelos qualitativos (DURÃES; MELLO, 2016; SILVA; LUCHIARI, 2016; LEZONIER et al., 2016).

A Equação Universal de Perda de Solos (EUPS), proposta por Wischmeier e Smith (1958) quando especializada por meio de um Sistema de Informaçóes Geográficas (SIG) permite uma análise da perda de solo por erosão laminar, possibilitando configurar os resultados obtidos em função do uso e ocupação do solo. Assim, este estudo teve por objetivo estimar a perda de solos por erosão laminar na bacia hidrográfica do Ribeirão João Leite no ano de 2011, utilizando um Sistema de informaçóes geográficas (software ArcGis 9.3).

\section{FUNDAMENTAÇÃO TEÓRICA}

Uma bacia hidrográfica é composta por um conjunto de superfícies vertentes e de uma rede de drenagem formada por cursos d'água que confluem até resultar um leito único no exultório. É definidora dos cursos de água as características geográficas e topográficas da bacia, sempre da parte mais alta para a mais baixa. Deve-se considerar que uma bacia hidrográfica normalmente é formada por várias bacias secundárias ou sub-bacias interligadas. Sendo essencial a comparação de sub-bacia como uma bacia menor dentro da totalidade da bacia hidrográfica principal. Machado (2010) ressalta que a bacia hidrográfica referese à área de drenagem do rio principal; a sub-bacia abrange a área de drenagem de um tributário do rio principal e a microbacia abrange a área de drenagem de um tributário do rio principal. Sendo determinado como tributário os cursos d'água que compóem a bacia hidrográfica. De qualquer forma, todos os cursos d'água de uma determinada bacia vão dar, direta ou indiretamente, no rio principal do sistema que, em geral, dá nome ao conjunto da bacia hidrográfica.

As práticas conservacionistas fazem-se importantes, porém em áreas de bacias hidrográficas, sua aplicação demanda atenção mais acentuada. $\mathrm{O}$ controle de processos erosivos, que prejudicam o meio natural, deve ser prática constante. Este processo de degradação do solo, que pode ocorrer de forma natural, costuma ser acelerado e acentuado pela ação antrópica.

A erosão laminar retira a camada de terra superficial da superfície terrestre, remove também a fertilidade dos solos, em função da retirada de nutrientes e sedimentos minerais, por meio do escoamento superficial (OLIVEIRA et al., 2013; SOUZA; SOBREIRA, 2017).

A erosão laminar dá-se durante a incidência das precipitações, onde parte da água é interceptada pela vegetação, enquanto o restante atinge a superfície do solo, umedecendo os agregados do solo e reduzindo suas forças de coesão. Com a continuidade das chuvas ocorre à desintegração dos agregados em partículas menores, obstruindo os poros do solo, consequentemente provocando o selamento superficial. Além disso, o impacto da gota de chuva proporciona compactação, que associada ao selamento, reduz a taxa de infiltração da água. Quando a intensidade da chuva passa a ser maior do que a taxa de infiltração, inicia-se o transporte das partículas desagregadas do solo pelo escoamento superficial (GRISMER, 2012).

Em um Decreto Estadual de 27 de dezembro de 2002, de No 5.704, foi criada a Área de Preservação Permanente (APA) João Leite. A criação da APA determina que toda 
área da bacia hidrográfica do Ribeirão João Leite deve ser protegida e monitorada de forma constante. A responsabilidade de tal ação recai sobre a Secretaria do Meio Ambiente e dos Recursos Hídricos (SEMARH), prevendo que a mesma tem autonomia para firmar convênios e acordos com entidades públicas ou privadas.

Em fevereiro de 2011 foi lançado um consórcio intermunicipal da APA do João Leite, reunindo os municípios de Campo Limpo, Goianápolis, Nerópolis, Ouro Verde e Terezópolis de Goiás, visando à participação das comunidades locais na gestão ambiental da APA, bem como a elaboração de políticas integradas e aprovação de incentivos fiscais para empresas não poluentes.

\section{MATERIAIS E MÉTODOS}

Inicialmente foi obtido um conjunto de mapas temáticos da bacia hidrográfica do Ribeirão João Leite em órgãos oficiais do Estado de Goiás. Os mapas de tipos de solos, de uso da terra e cobertura vegetal natural, da bacia hidrográfica, no formato Shapefile. Os mapas foram obtidos do Sistema Estadual de Estatística e Informaçóes Geográfica de Goiás (SIEG), no site www.sieg.go.gov.br, e a imagem do radar SRTM folha, SE-22-X-B foi obtido na Empresa Brasileira de Pesquisa Agropecuária (Embrapa), no do site www.relevobr. cnpm.embrapa.br.

Posteriormente, efetuou-se no software Arcgis 9.3, o recorte do mapa da bacia do Ribeirão João Leite utilizado como máscara de todos os outros mapas. Com a máscara da bacia recortada, foi extraído o mapa dos tipos dos solos predominantes na bacia, de uso do solo e cobertura vegetal natural. Por meio da imagem do radar SRTM foi gerado o Modelo Digital de Terreno (MDT) da bacia. A seguir foram calculadas as variáveis da EUPS erosividade das chuvas (R) por meio dos dados da Agência Nacional de Água (ANA), o mapa de erodibilidade dos solos $(\mathrm{K})$, o mapa de uso e manejo dos solos $(\mathrm{C})$ e as práticas conservacionistas $(\mathrm{P})$.

Foram gerados os mapas temáticos e o modelo digital de terreno da área de estudo para o cálculo das variáveis da EUPS no SIG. Essas variáveis (conjunto de mapas temáticos e índices) possibilitaram o cálculo da EUPS. São apresentados os seguintes mapas finais: mapa do fator topográfico (LS) da área de estudo, constituído pelo cruzamento do mapa de rampa (L) e de declividade (S); mapa do potencial natural à erosão laminar (PNE) decorrente do cruzamento do fator de erosividade das chuvas $(\mathrm{R})$, do mapa de erodibilidade dos dolos (K) e do fator topográfico (LS); e, mapa de perda de solo por erosão laminar (A) decorrente da integração das variáveis físicas com as variáveis antrópicas, ou seja:

$$
\mathrm{A}=\text { R.K.L.S.C.P ou A= PNE.C.P }
$$

Onde:

A - Perda de solo em unidade de massa por unidade de área e unidade de tempo (ton $/ \mathrm{km}^{2}$.ano); $\mathrm{R}$ - Fator relativo à erosividade das chuvas (ton $/ \mathrm{km}^{2}$.ano); $\mathrm{K}-$ Fator de erodibilidade do solo (t.h/(MJ.mm)); L - Rampa (m); S - Declividade (\%); PNE - Potencial natural à erosão laminar (ton $/ \mathrm{km}^{2}$.ano); $\mathrm{C}$ - Fator de uso/manejo do solo (adimensional); $\mathrm{P}$ - Fator de práticas conservacionistas de solo (adimensional). 


\subsection{Caracterização da área de estudo}

A bacia hidrográfica do Ribeirão João Leite compreende abrange sete municípios do Estado de Goiás (BARBOSA; LIMA, 2006): Ouro Verde, Campo Limpo, Nerópolis, Terezópolis de Goiás, Goianápolis, Anápolis e Goiânia. O Manancial possui uma área de aproximadamente $770 \mathrm{~km}^{2}$ e $130 \mathrm{~km}$ de extensão. Compóe a Bacia Hidrográfica do Rio Paranaíba e é um dos principais afluentes do Rio Meia Ponte. O Ribeirão João Leite é um dos três principais abastecedores de água da capital do Estado de Goiás, Goiânia e de cidades vizinhas. A Barragem João Leite é uma obra que prevê a garantia do abastecimento público de água para a populaçáo de Goiânia e cidades vizinhas pela Empresa Saneamento de Goiás S/A (SANEAGO), até o ano de 2025 para mais de 1,5 milhóes de habitantes.

Conforme o Relatório da Macrozona Rural do Ribeirão João Leite elaborado pela Prefeitura de Goiânia (2008), o clima da bacia é do tipo tropical, caracterizado por duas estaçóes bem definidas, uma seca, que vai de maio a setembro e outra chuvosa que vai de outubro a abril, período em que ocorrem chuvas torrenciais. A temperatura média anual do ar é de $23^{\circ} \mathrm{C}$, com mínima de $15^{\circ} \mathrm{C}$ e máxima de $42^{\circ} \mathrm{C}$.

\subsection{Coleta de dados}

Para a realização do presente estudo foram utilizados os seguintes materiais:

- Três bases cartográficas do Estado de Goiás, obtidas por meio do Sistema Estadual de Estatística e Informaçóes Geográfica de Goiás (SIEG), no site www.sieg.go.gov. br, composta por arquivos vetoriais no formato digital, com extensão *.shp, contendo informaçóes sobre a bacia hidrográfica, uso do solo e cobertura vegetal natural, e tipos de solos. Na escala 1:250.000, projeção UTM, Meridiano Central - 51W, Datum Horizontal: SAD-69, Zona 22 S. Sistema de Coordenadas Geográficas Latitude e Longitude;

- Dados pluviométricos de precipitação obtidos das estaçóes meteorológicas da Agência Nacional de Água (ANA), localizadas nos Municípios de Ouro verde (com código 01649009), de Goianápolis (código 01649004) e de Goiânia (Faculdade de Agronomia, instalada na Universidade Federal de Goiás, com código 01649005); e,

- Uma imagem de Radar SRTM, com resolução espacial de 90 m, adquirida na Empresa Embrapa no site www.relevobr.cnpm.embrapa.br, na escala 1:250.000, projeção UTM, Meridiano Central - 51W, Datum: WGS-84, Zona 22 S. Sistema de Coordenadas Geográficas, folha SE-22-X-B;

- Programa Gerenciador de Informaçóes Geográficas (PGIG) ArcGis na versão 9.3.

\subsection{Geraçáo dos mapas temáticos e do modelo digital de terreno para o cálculo da EUPS}

Para a realização do cálculo da Equação Universal de Perda de Solos (EUPS) foi necessária à geração de mapas temáticos da área de estudo. Os mapas temáticos gerados foram: mapa da Bacia Hidrográfica do Ribeirão João Leite (máscara); mapa dos tipos de solos; mapa de uso do solo e cobertura vegetal natural; e, mapa do modelo digital de terreno (MDT). 


\subsection{Mapa da Bacia Hidrográfica do Ribeiráo João Leite}

Para recortar o mapa da Bacia Hidrográfica do Ribeirão João Leite foi necessário fazer o download de todas as bacias hidrográficas do Estado de Goiás no site do SIEG (FIGURA 1a).

O mapa da Bacia Hidrográfica do Ribeirão João Leite (FIGURA 1b) recortado, foi utilizado como base para os recortes nos demais mapas temáticos gerados.

Foram utilizadas as seguintes ferramentas do software ArcGis 9.3 para o recorte da máscara:

- select features, para selecionar a bacia; e,

- clip, para recortar o vetor da bacia.

Figura 1 - 1a. Localização da Bacia do Ribeirão João Leite (azul), que faz parte das bacias hidrográficas situadas na região sul do Estado de Goiás; 1b - Mapa da Bacia Hidrográfica do Ribeirão João Leite

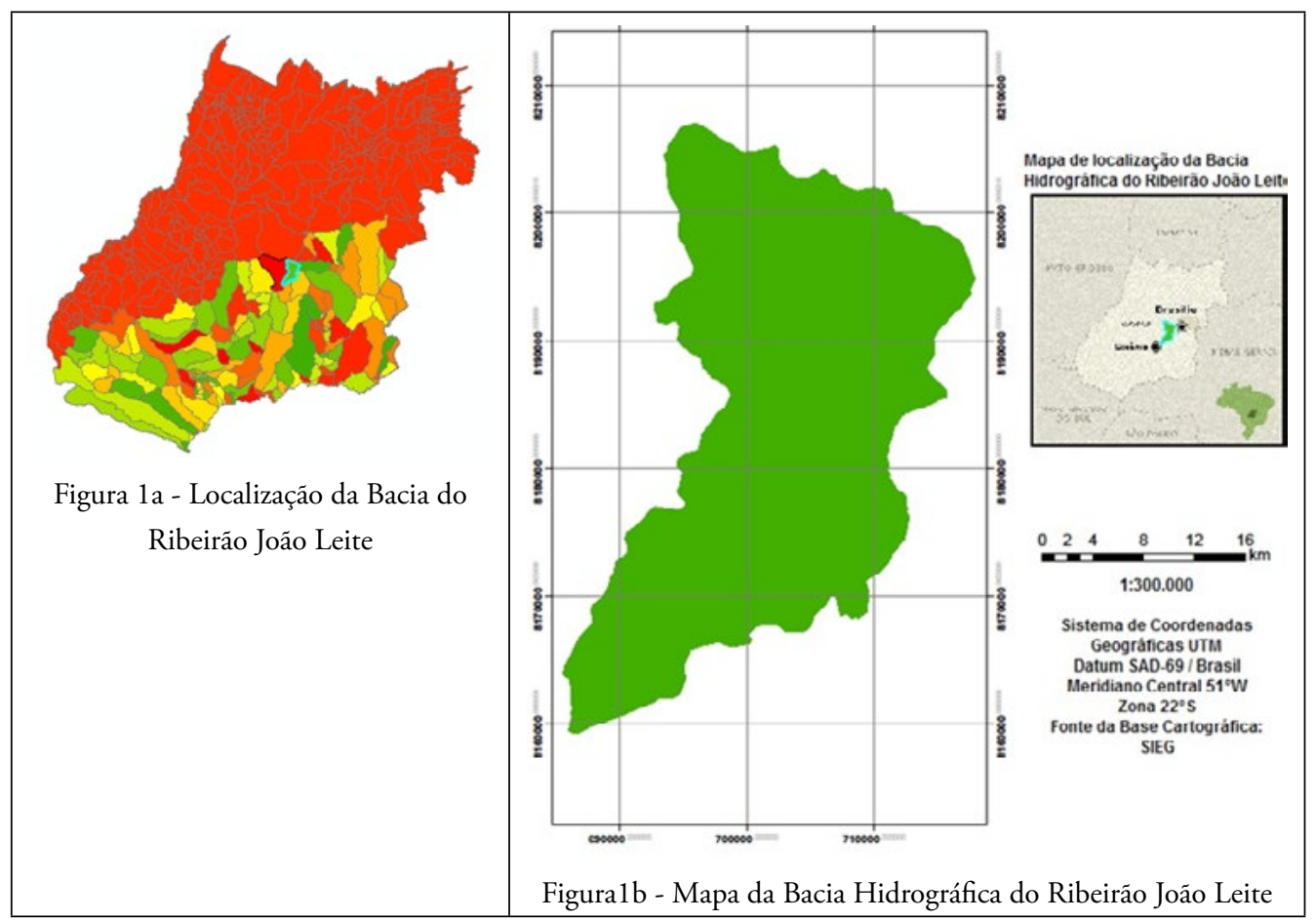

Fonte: Adaptado do SIEG (2010).

\subsection{Confecção do Mapa dos tipos de solos}

Foi efetuado o download do arquivo com os tipos de solos do Estado de Goiás, disponível no site do SIEG. Posteriormente, o arquivo foi importado para o software ArcGis 
9.3. O mapa dos Tipos de Solos da Bacia do Ribeirão João Leite (Figura 2), foi gerado utilizando o vetor do mapa da Bacia do João Leite como máscara e a ferramenta clip.

\subsection{Mapa de uso do solo e cobertura vegetal natural}

Para o mapa de uso do solo e cobertura vegetal natural foi efetuado o download do mapa de uso do solo e cobertura vegetal natural do Estado de Goiás, disponível no site do SIEG, e posteriormente importado para o software ArcGis. Com os arquivos importados foi recortado o mapa uso da terra e cobertura vegetal natural da bacia do Ribeirão João Leite utilizando o vetor da Bacia do João Leite como máscara. Foi utilizada a ferramenta clip para confeccionar o recorte.

\subsection{Modelo digital de terreno (MDT)}

O MDT da Bacia Hidrográfica do Ribeirão João Leite foi elaborado em ambiente digital a partir de imagem SRTM distribuída pela Embrapa no site www.relevobr.cnpm. embrapa.br/download/go/go.htm. Na escala 1:250.000, Sistema de coordenadas Geográficas e Datum WGS-84, Carta SE-22-X-B. Para gerar o MDT foi necessário fazer o download das imagens do radar SRTM do site da Embrapa e inserir as mesmas no software ArcGis. Posteriormente, foi realizado o recorte da imagem utilizando o vetor da Bacia do João Leite como máscara. Para tanto, foi utilizado a ferramenta Extract by Mask.

\subsection{Conversão de WGS 84 para SAD 69}

Como os dados dos mapas gerados encontravam-se no Sistema de Projeção UTM, Meridiano Central - 51W, Datum SAD-69, Zona 22S e o MDT no Datum WGS-84, foram necessários converter o Modelo para o mesmo Sistema de Coordenadas. Optouse pelo Datum Horizontal SAD-69. No software ArcGis foi utilizada a ferramenta Project Raster para a execução desse processo. Para ser realizado o cruzamento das informaçóes entre os mapas e o MDT o tamanho do pixel foi padronizado em 90 metros. Para tanto foi utilizada a ferramenta resample do software ArcGis 9.3.

\subsection{Erosividade das Chuvas (R)}

$\mathrm{Na}$ área da bacia existem estaçóes pluviométricas que fornecem dados de precipitação a cada 24 horas e de variação do nível de água e vazão. Os dados de precipitação foram obtidos das estações meteorológicas da ANA, localizadas em Ouro Verde, Goianápolis e Goiânia, por meio do Relatório Síntese da Macrozona Rural do Ribeirão João Leite, site http://www.goiania.go.gov.br.

\subsection{Erodibilidade dos Solos $(\mathbf{K})$}

Os valores de K utilizados foram obtidos de Denardin (1990), Levy (1995), Baptista (1997) e Bertoni e Lombardi Neto (1990). Os valores de erodibilidade foram associados às respectivas categorias do solo. 


\subsection{Confecção do mapa do uso e manejo dos solos $(\mathrm{C})$}

As classes do mapa de uso e manejo dos solos (C) foram obtidas de acordo com o mapa de uso da terra e cobertura vegetal natural da bacia do Ribeirão João Leite e refere-se à participação antrópica no processo. Os valores atribuídos para C (TABELA 1), em cada classe estabelecida, foram obtidos de Stein et al. (1987).

No software ArcGis foi criada uma nova coluna com os valores de C atribuídos, no mapa de uso da terra e cobertura vegetal natural da Bacia do Ribeirão João Leite.

Tabela 1 - Valores de C em função das classes de cobertura vegetal natural

\begin{tabular}{c|c}
\hline Uso do solo e Cobertura Vegetal Natural & Valores de C \\
\hline Agricultura & 0,018 \\
\hline Pastagem & 0,010 \\
\hline Área Urbana & 0,010 \\
\hline Cerrado & 0,0007 \\
\hline Floresta & 0,00004 \\
\hline
\end{tabular}

Fonte: Stein et al. (1987).

\subsection{Definiçáo do valor do índice de práticas conservacionistas $(P)$}

Dada a grande extensão acentuada da bacia e a falta de dados disponíveis para a definição do índice de práticas conservacionistas optou-se por considerar a sua não existência.

\subsection{Cálculo do fator topográfico (LS)}

A variável LS é a associação dos fatores comprimento de rampa (L) e declividade (S). Essa associação é dada pela Equação 3, que foi adaptada por Bertoni em 1965 para o Estado de São Paulo:

$\mathrm{LS}=0,00984 \cdot \mathrm{L}^{0,63} \cdot \mathrm{S}^{1,18}$

onde,

$\mathrm{LS}$ = fator topográfico (adimensional);

$\mathrm{L}=$ comprimento de Rampa (m); e,

$\mathrm{S}=$ declividade $(\%)$.

Cálculo do comprimento de rampa (L)

O Fator L não possui obtenção direta, portanto, foi realizado o cálculo utilizando a Equação 4, proposta por Rocha et al. (1995).

$\mathbf{L}=\frac{\mathrm{DH}}{\operatorname{sen} \alpha}$

onde:

$\mathrm{DH}=$ diferença de Altitude (m); 
$\alpha=$ declividade Média da Rampa (graus); e,

$\mathrm{L}=$ comprimento de rampa $(\mathrm{m})$.

Para a obtenção do fator comprimento de rampa (L) foi necessária a confecção do mapa do fator $\mathrm{DH}$ e de $\alpha$ (declividade média das rampas).

De acordo com Stein et al. (1987) o Potencial Natural de Erosão (PNE) é a integração dos principais fatores naturais do meio físico intervenientes no processo de erosão laminar. Ele é dado pela Equação 5:

$\mathrm{PNE}=$ K.R.LS

onde,

$\mathrm{K}$ - fator de erodibilidade do solo (ton.ha.h./ha.MJ.mm);

$\mathrm{R}$ - fator de erosividade da chuva (MJ.mm/ha.h.ano); e,

LS - fator topográfico.

O fator PNE foi calculado, utilizando a ferramenta Raster Calculator, no software ArcGis.

\subsection{Confecção do mapa do fator $\mathrm{DH}$}

O mapa do fator DH foi confeccionado a partir do cruzamento do mapa de rampas homogêneas com o do MDT do Ribeirão João Leite. O mapa de rampas homogêneas por sua vez é elaborado a partir do cruzamento do mapa de declividade em porcentagem reclassificado com o de aspecto reclassificado. Portanto, para a elaboração do mapa DH temse que confeccionar: MDT da Bacia do Ribeirão João Leite; mapa de aspecto reclassificado; mapa de declividade em porcentagem reclassificado; e, mapa de rampas homogêneas (transformado em polígonos).

\subsection{Confecçáo do mapa de aspecto reclassificado}

O aspecto é o ângulo de exposição das vertentes em relação ao norte, ou seja, indica direção do fluxo e varia de $0^{\circ}$ a $360^{\circ}$. Foi obtido por meio do MDT gerado, utilizando para tanto a ferramenta Aspect. O mapa de aspecto foi editado para visualização em oito classes, de $45^{\circ}$ em $45^{\circ}$, utilizando a ferramenta Reclassify.

\subsection{Confecçáo do mapa de declividade em porcentagem reclassificado}

O mapa de declividade em porcentagem foi obtido não só para obter o mapa de $\mathrm{DH}$, como também para obter o do fator topográfico (LS). E foi obtido utilizando-se da ferramenta Slope, no software Arc Gis. Posteriormente, o mapa de declividade em porcentagem foi reclassificado utilizando a ferramenta Reclassify, no software ArcGis.

\subsection{Confecçáo do mapa de rampas homogêneas reclassificado}

O Mapa de rampas homogêneas é a combinação do mapa de declividade em porcentagem reclassificado, com o de aspecto reclassificado e posteriormente agrupado 
em polígonos, de onde foi extraído o mapa de diferença de altitude (DH) e $\alpha$ (Alfa). Foi obtido por meio da ferramenta combine, no software ArcGis e transformado em polígonos, utilizando a ferramenta Raster to Features.

\subsection{Confecçáo do mapa de diferença de altitude (DH)}

O Mapa de diferença de altitude (DH) é a diferença de altura da rampa (metros) e foi obtido pelo cruzamento do mapa de rampas homogêneas reclassificado com o MDT da Bacia do Joáo Leite, por meio da ferramenta Zonal Statistics, no software ArcGis.

\subsection{Confecçáo do mapa declividade média de rampa - graus $(\alpha)$}

O Mapa Declividade Média de Rampa - Graus ( $\boldsymbol{\alpha}$ ) é a declividade média do polígono (graus), constituído pelo cruzamento do mapa de rampas homogêneas reclassificado com o de declividade em graus. O mapa de declividade em graus foi obtido por meio da ferramenta Slope, no software ArcGis, utilizando o MDT da Bacia do Ribeirão João Leite.

O mapa declividade média de rampa - graus $(\alpha)$ foi obtido por meio da ferramenta Zonal Statistics, no software ArcGis.

\subsection{Confecçáo do mapa do fator de comprimento de rampa $(L)$}

Com o mapa diferença de altitude $(\mathrm{DH})$ e o mapa declividade nédia de rampa graus $(\alpha)$ foi gerado o mapa do fator de comprimento de rampa (L), por meio da ferramenta Raster Calculator, no software ArcGis.

\subsection{Cálculo do mapa de perda de solos por erosáo laminar (A) reclassificado}

O mapa de perda de solos por erosão laminar é a integração das variáveis naturais com as antrópicas e foi gerada utilizando a ferramenta Raster Calculator, no software ArcGis. O mapa de perda de solos por erosão laminar na Bacia Hidrográfica do Ribeirão João Leite foi entấo reclassificado utilizando a ferramenta Reclassify, no software ArcGis.

\section{RESULTADOS E DISCUSSÓES}

\subsection{Mapa dos tipos de solos}

Na Figura 2 tem-se o mapa dos Tipos de Solos da Bacia do Ribeirão Joáo Leite. A Tabela 2 mostra os tipos de solo predominantes na Bacia Hidrográfica João Leite. 
Tabela 2 - Área correspondente a cada tipo de solo da Bacia do Ribeirão João Leite

\begin{tabular}{c|c|c}
\hline \multirow{2}{*}{ Tipos de Solos } & \multicolumn{2}{|c}{ Área } \\
\cline { 2 - 3 } & (ha) & $(\%)$ \\
\hline Gleissolo & 122,31 & 0,16 \\
\hline Cambissolo & $7.548,39$ & 9,87 \\
\hline Argissolo & $24.926,13$ & 32,56 \\
\hline Latossolo & $43.946,55$ & 57,41 \\
\hline Total & $76.543,3$ & 100,00 \\
\hline
\end{tabular}

Fonte: software ArcGis 9.3

Ao analisar os tipos de solo na área da bacia, pode-se identificar a predominância de dois tipos: latossolo e argissolo. O tipo de solo, juntamente com a pluviosidade, corresponde a um dos fatores fundamentais para o processo de erosão laminar (RORIZ et al., 2016).

O latossolo faz-se predominante, abrangendo mais da metade da área da bacia (57,41\%, conforme Tabela 2). Possui características intimamente ligadas à meteorização, ou seja, a fenômenos químicos e físicos que levam ao enfraquecimento das rochas. Também é característica do latossolo a solubilização de compostos químicos, consequente do fluxo da água através do solo (SANTOS, 2015).

O outro tipo de solo predominante na área da bacia é o argissolo, correspondendo a $32,56 \%$ (TABELA 2) da área total. Segundo Camargo (2009) os argissolos são conhecidos por sua capacidade de armazenamento de água às plantas por um tempo mais longo devido ao gradiente de textura no perfil destes solos e características estruturais, muito influenciadas pela mineralogia da argila. Possui em sua composição caulinita, gipsita, óxidos de ferro entre outros. $\mathrm{O}$ argissolo possui elevada fertilidade natural e não é pedregoso, sendo assim apto para a agricultura. Em áreas de elevado declive, possui tendências a problemas de erosão. Ocorre com frequência no Cerrado, porém não em áreas contínuas. Os outros tipos de solo presentes na área da bacia são: cambissolo $(9,87 \%)$ e gleissolo, correspondente a somente $0,16 \%$ (TABELA 2). 
Figura 2 - Mapa dos tipos de solos

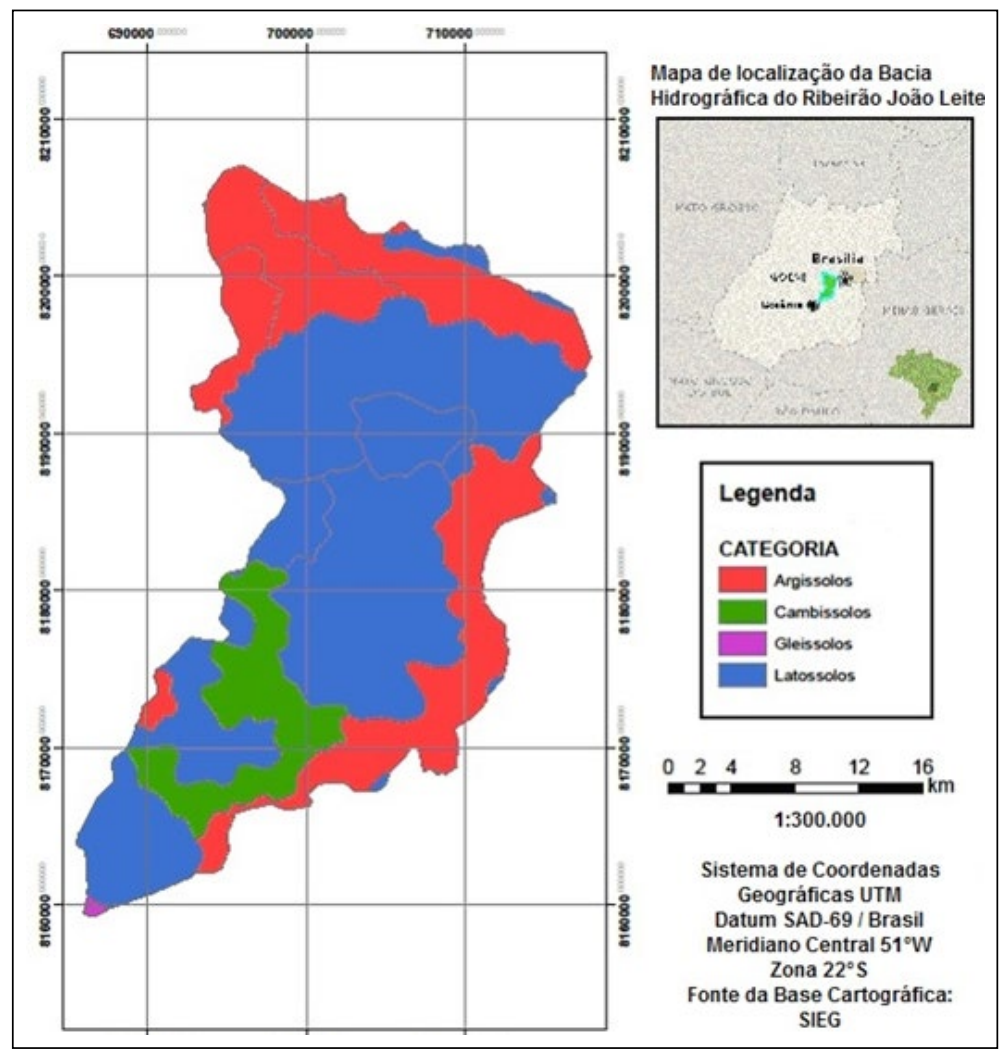

Fonte: Elaborado pelos autores.

\subsection{Mapa de uso do solo e cobertura vegetal natural}

$\mathrm{Na}$ Figura 3 é apresentado o mapa de uso da terra e cobertura vegetal natural da bacia do Ribeirão João Leite. E a Tabela 3 mostra as áreas de uso do solo e cobertura vegetal natural da Bacia Hidrográfica João Leite predominantemente de uso para agricultura seguida por pastagem e floresta.

Tabela 3 - Área correspondente a cada tipo de uso do solo e cobertura vegetal natural solo da Bacia do Ribeiráo João Leite

\begin{tabular}{c|c|c}
\hline \multirow{2}{*}{$\begin{array}{c}\text { Uso da Terra e Cobertura } \\
\text { Vegetal Natural }\end{array}$} & $(\mathrm{ha})$ & Área \\
\cline { 2 - 3 } & $48.809,79$ & 63,77 \\
\hline Agricultura & $15.764,22$ & 20,59 \\
\hline Pastagem & $2.916,00$ & 3,81 \\
\hline Área Urbana & $1.308,96$ & 1,71 \\
\hline Cerrado & &
\end{tabular}




\begin{tabular}{c|c|c}
\hline \multirow{2}{*}{$\begin{array}{c}\text { Uso da Terra e Cobertura } \\
\text { Vegetal Natural }\end{array}$} & $(\mathrm{h})$ & Área \\
\cline { 2 - 3 } & $7.744,41$ & 10,12 \\
\hline Floresta & $76.543,38$ & 100,00 \\
\hline Total & & \\
\hline
\end{tabular}

Fonte: software ArcGis 9.3.

Analisando o mapa de uso do solo e cobertura vegetal natural da bacia foi observado que parte da área possui predominância de com pastagem e floresta, o que faz entre outros, manter a cobertura vegetal natural. Por esse motivo, o mapa de perda de solos por erosão laminar possui maior predominância das áreas de muito baixo ou baixo potencial. Os fatores do mapa de comprimento de rampa, de declividade e a erosividade das chuvas também estão relacionados a esse resultado, pois são os fatores mais importantes da equação e tiveram resultados satisfatórios, de baixa propensão à erosão laminar.

Figura 3 - Mapa de uso do solo e cobertura vegetal natural

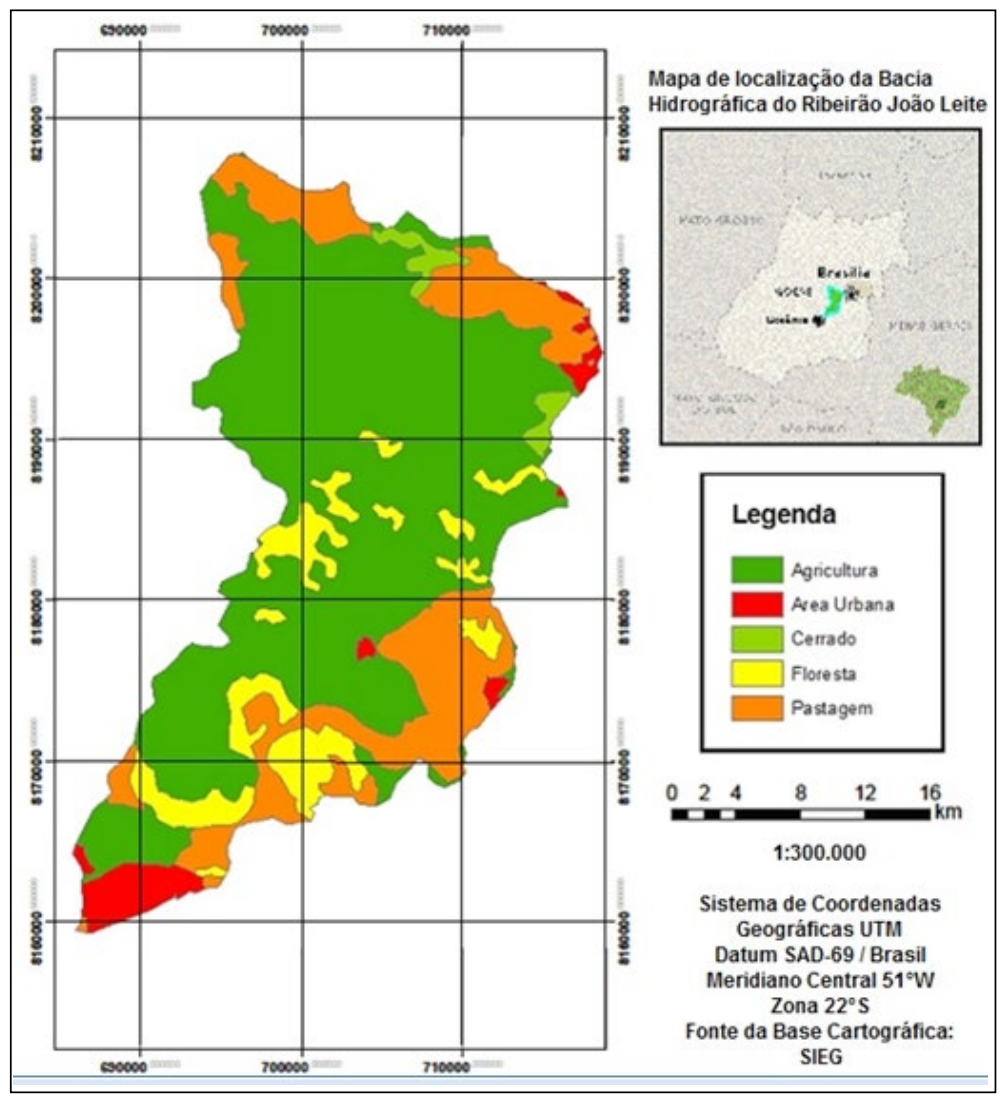

Fonte: Elaborado pelos autores. 


\subsection{Variáveis da EUPS no Sistema de informaçóes geográficas}

\subsubsection{Erosividade das Chuvas ( $R$ )}

A média mensal do índice de erosão para cada mês chegou-se ao valor de chuva média anual de $1.602,7 \mathrm{~mm}$. A Tabela 4 apresenta os valores de precipitação média mensal e erosividade $(\mathrm{Ei})$, apresenta os valores de precipitação média mensal e erosividade para o período de 20 anos. $\mathrm{O}$ valor de precipitação média anual na área da bacia do Ribeirão João Leite é de 1.602,70 mm coerente com o que chove em Goiânia de aproximadamente $1.487,2 \mathrm{~mm}$ e relativamente homogênea. Em pesquisa realizada por Pereira et al. (2015) na bacia do Córrego Cascavel em Goiás a precipitação no ano de 2015 variou de 1.000 a 1.900 $\mathrm{mm}$. Assim como no presente trabalho Pereira et al. (2015) constataram que os maiores índices de erosividade se encontravam nas áreas com maiores intensidades de pluviosidade. Contudo, ressalta-se que a erosividade depende de como a precipitação se distribui ao longo do ano.

Tabela 4 - Apresentação dos valores de precipitação média mensal e erosividade para a Bacia do Ribeirão João Leite

\begin{tabular}{c|c|c}
\hline Mês & Média Mensal $(\mathrm{mm})$ & Ei (ton $/ \mathrm{km}^{2}$.ano $)$ \\
\hline Janeiro & 269,20 & 175,78 \\
\hline Fevereiro & 207,90 & 113,29 \\
\hline Março & 237,90 & 142,46 \\
\hline Abril & 116,60 & 42,38 \\
\hline Maio & 37,80 & 6,24 \\
\hline Junho & 9,60 & 0,60 \\
\hline Julho & 6,10 & 0,28 \\
\hline Agosto & 15,60 & 1,38 \\
\hline Setembro & 49,20 & 9,77 \\
\hline Outubro & 156,50 & 69,90 \\
\hline Novembro & 225,70 & 130,27 \\
\hline Dezembro & 270,60 & 177,33 \\
\hline Anual & $1.602,70$ & 869,69 \\
\hline
\end{tabular}

Fonte: Adaptado de ANA (2008).

\subsubsection{Erodibilidade dos Solos (K)}

A Tabela 5 apresenta os valores de erodibilidade, a quantidade de perda de solo por erosão laminar para cada tipo de solo. Alguns solos são mais suscetíveis a erodir que outros, mesmo quando o declive, a precipitação, a cobertura vegetal e as práticas de manejo sejam as mesmas. Isso ocorre em função das propriedades inerentes ao solo que afetam a maior ou a menor facilidade à erosão. Estas propriedades estão relacionadas à velocidade de infiltração, 
permeabilidade, capacidade de armazenamento, resistência às forças de dispersão, salpico, abrasão e transporte pela chuva e escoamento (CEMIN et al., 2013). Para Pereira et al. (2015) a erodibilidade do solo para a Cidade de Goiânia e o Estado de Goiás variam entre 0,009 e 0,014 t.h/(MJ.mm) contudo, para o presente trabalho os valores encontrados são em predominância de 0,016 a 0,033 t.h/(MJ.mm).

Tabela 5 - Valores de erodibilidade dos solos

\begin{tabular}{c|c}
\hline Classes de Solos & Erobilidade (K) em t.h/(MJ.mm) \\
\hline Gleissolo & 0,058 \\
\hline Cambissolo & 0,024 \\
\hline Argissolo & 0,033 \\
\hline Latossolo & 0,015 \\
\hline
\end{tabular}

Fonte: Denardin (1990), Levy (1995), Baptista, (1997), Bertoni e Lombardi Neto (1990)

$\mathrm{Na}$ Figura 4 tem-se o mapa de erodibilidade do solo para a Bacia do Ribeirão João Leite com predomínio de classes de solos Latossolo e Argissolo.

Figura 4 - Mapa de erodibilidade do solo para a Bacia Hidrográfica do Ribeirão João Leite

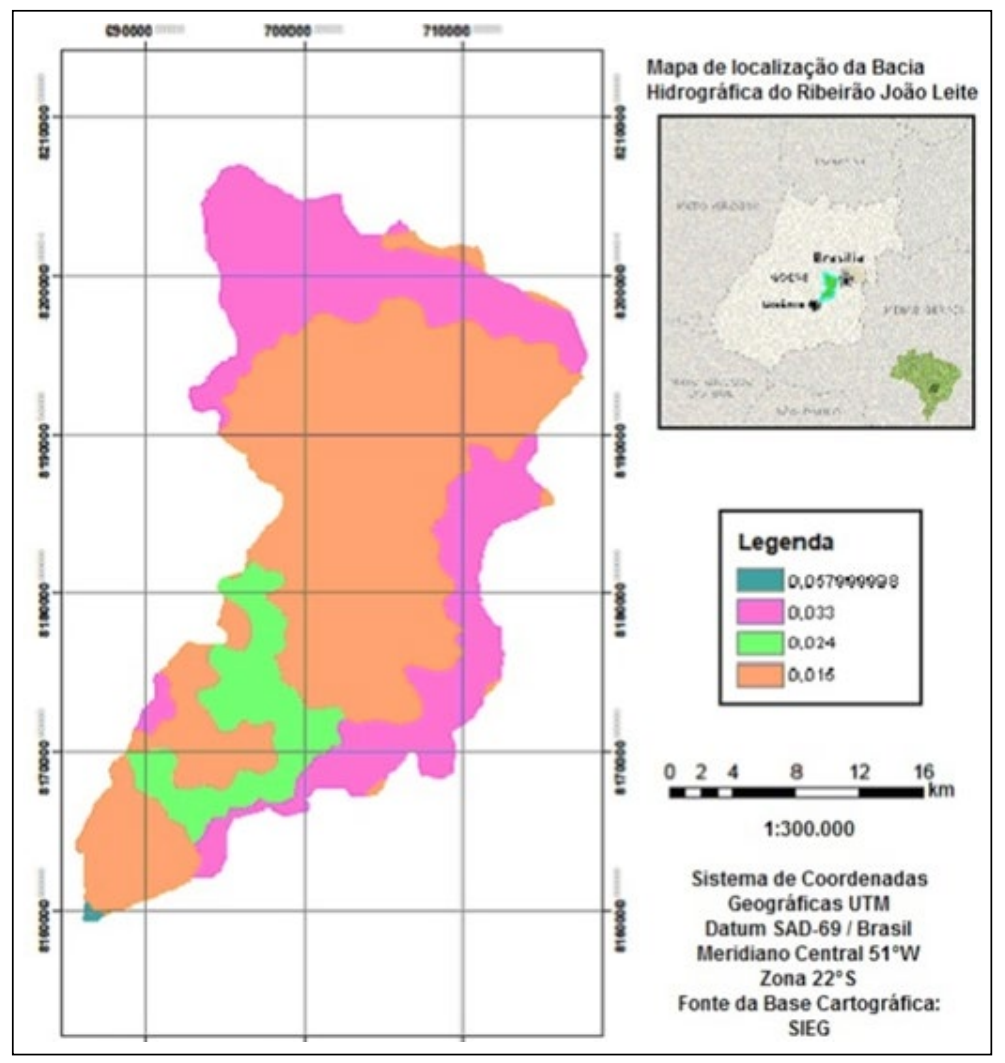

Fonte: Elaborado pelos autores. 


\subsubsection{Confecçáo do mapa do uso e manejo dos solos (C)}

O mapa de uso e manejo dos solos é apresentado na Figura 5. Os valores de $\mathrm{C}$ em função das classes de cobertura vegetal natural estabelecem dados de erosão laminar levando em consideração o uso do solo e a cobertura vegetal natural na região da bacia. Para Celmin et al. (2013) a cobertura vegetal exerce uma importante função na atenuação das perdas de solo, constituindo um sistema natural contra a erosão. No mapa do uso e manejo dos solos na Figura 5 verifica-se o predomínio de uso para agricultura seguida por floresta e pastagem.

Figura 5 - Mapa do uso e manejo dos solos (Fator C - uso do solo e cobertura vegetal natural)

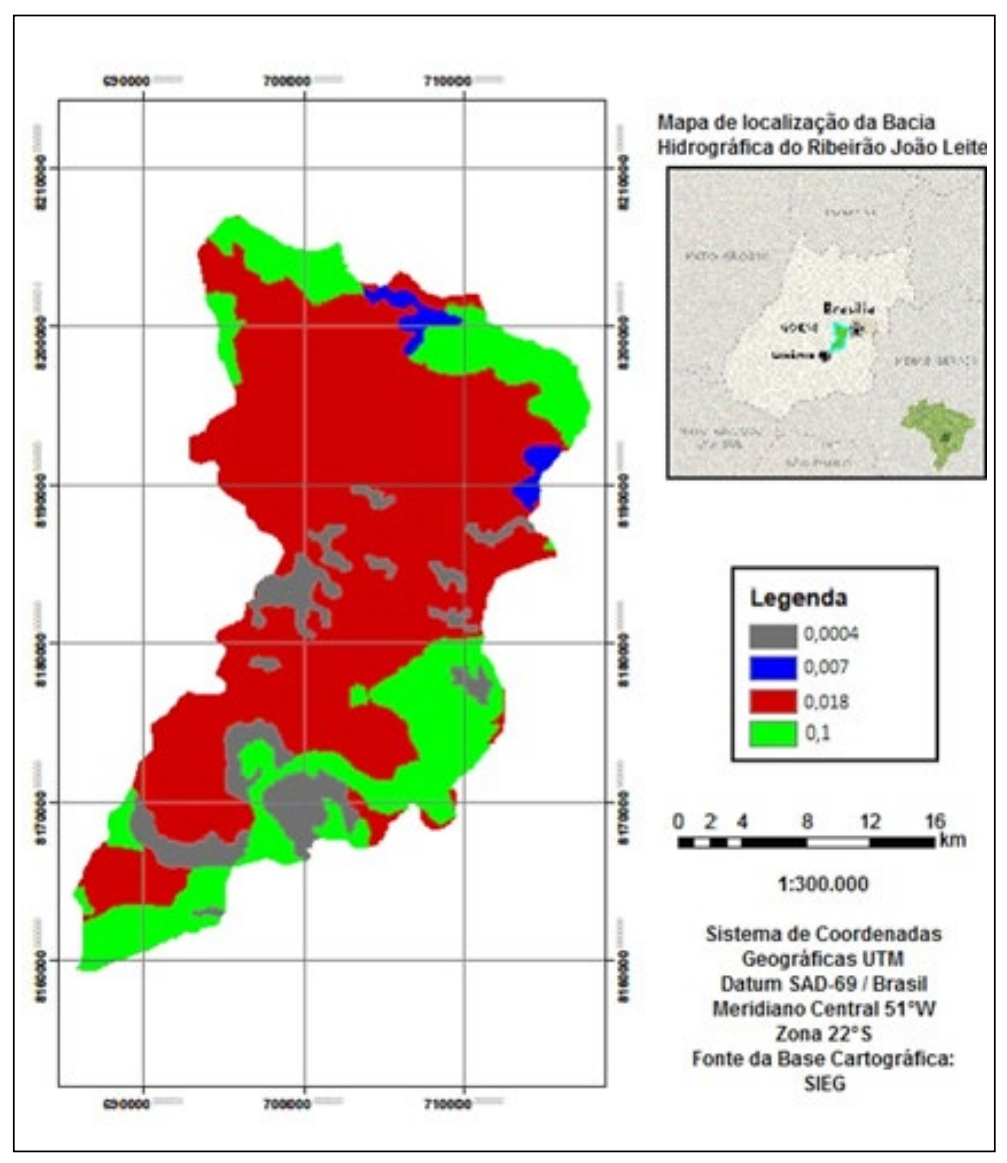

Fonte: Elaborado pelos autores.

\subsubsection{Definiçáo do valor do índice de práticas conservacionistas $(\mathrm{P})$}

$\mathrm{O}$ fator $\mathrm{P}$ foi desconsiderado da análise. Assim, foi adotado o valor máximo do parâmetro $\mathrm{P}=1,0$. $\mathrm{O}$ valor de $\mathrm{P}$ influencia diretamente no resultado final da estimativa de perda de solo por erosão laminar (fator A), sendo que quanto mais práticas conservacionistas na área menor serão o $\mathrm{P}$ e em consequência menor será a perda de solo por erosão laminar. 
As práticas conservacionistas adotadas em regiōes de culturas anuais são os plantios em contorno, em faixas de contorno, terraceamento e alternância de capinas. Assim como em pesquisa realizada por Celmin et al. (2013) na bacia do Arroio Marrecas, no Rio Grande do Sul, considerou-se que no presente estudo não há a adoção de práticas conservacionistas nas áreas de lavouras.

\subsubsection{Confecçáo do mapa de aspecto reclassificado}

Na Figura 6 é apresentado o mapa de aspecto e na Tabela 6 os índices correspondentes a cada direçấo dada para reclassificação do mapa de aspecto.

Tabela 6 - Índices correspondentes a cada direção dada para a reclassificaçấo do mapa de aspecto

\begin{tabular}{c|c}
\hline Direção & Índice \\
\hline Norte & 1 \\
\hline Nordeste & 2 \\
\hline Leste & 3 \\
\hline Sudeste & 4 \\
\hline Sul & 5 \\
\hline Sudoeste & 6 \\
\hline Oeste & 7 \\
\hline Noroeste & 8 \\
\hline
\end{tabular}

Fonte: software ArcGis 9.3. 
Figura 6 - Mapa de Aspecto

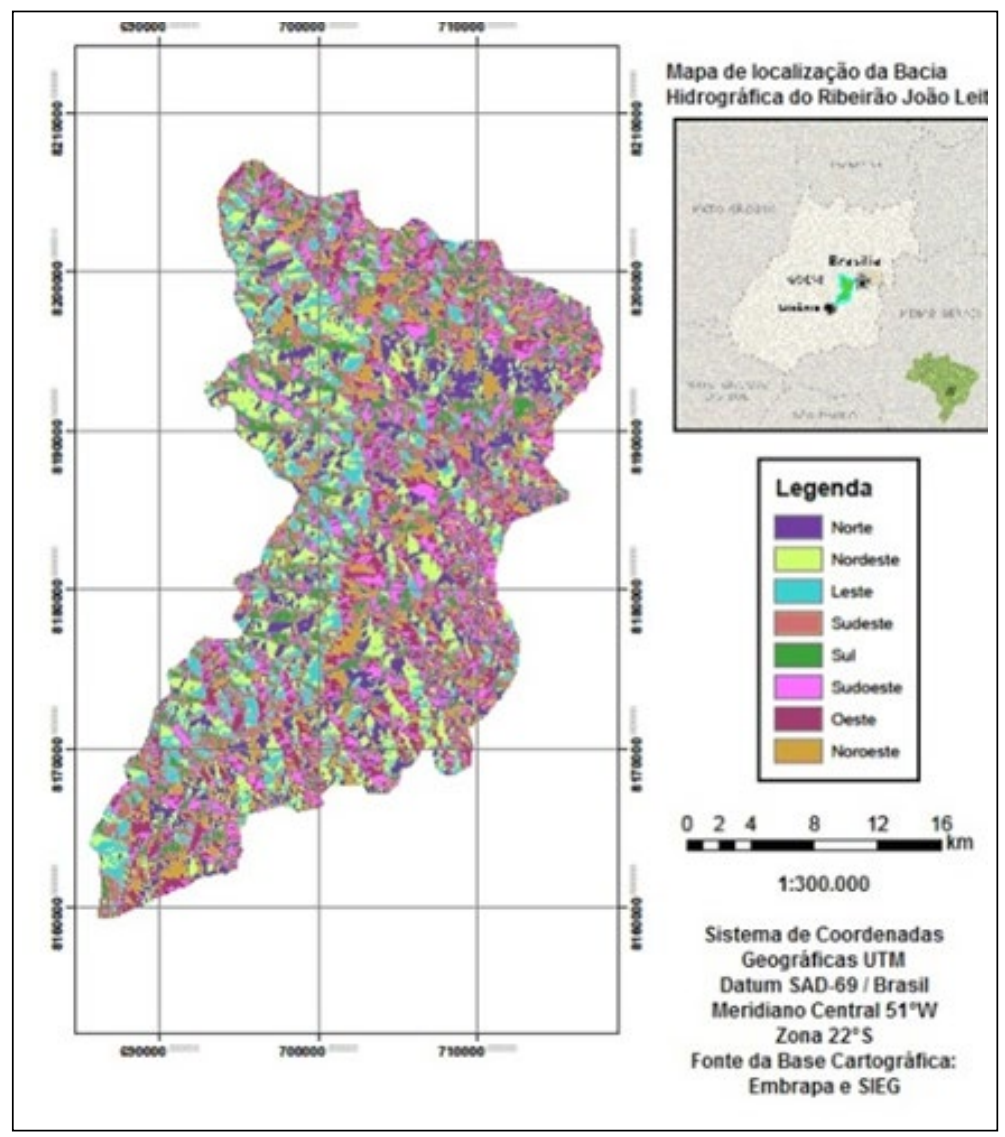

Fonte: Elaborado pelos autores.

\subsubsection{Confecçáo do mapa de declividade em porcentagem reclassificado}

$\mathrm{Na}$ Figura 7 tem-se o mapa de declividade em porcentagem reclassificado. A Tabela 7 mostra as áreas ocupadas pelas classes de declividade na Bacia do Ribeirão João Leite. Diferentemente dos valores encontrados por Pereira et al. (2015) na bacia do Córrego Cascavel apresenta área com poucas elevaçóes, a declividade para a bacia do Ribeirão João Leite é acentuada com aproximadamente $40 \%$ da área variando de 8 a $20 \%$. 
Tabela 7- Área ocupada pelas classes de declividade

\begin{tabular}{c|c|c}
\hline \multirow{2}{*}{ Declividade (\%) } & \multicolumn{2}{|c}{ Área } \\
\cline { 2 - 3 } & (ha) & $(\%)$ \\
\hline Menor que 3 & $8.518,77$ & 11,13 \\
\hline 3 a 8 & $34.344,81$ & 44,87 \\
\hline 8 a 20 & $30.344,22$ & 39,64 \\
\hline Maior que 20 & $3.335,58$ & 4,36 \\
\hline Total & $76.543,38$ & 100,00 \\
\hline
\end{tabular}

Fonte: software ArcGis 9.3.

Figura 7 - Mapa de declividade em porcentagem (Área ocupada pelas classes de declividade)

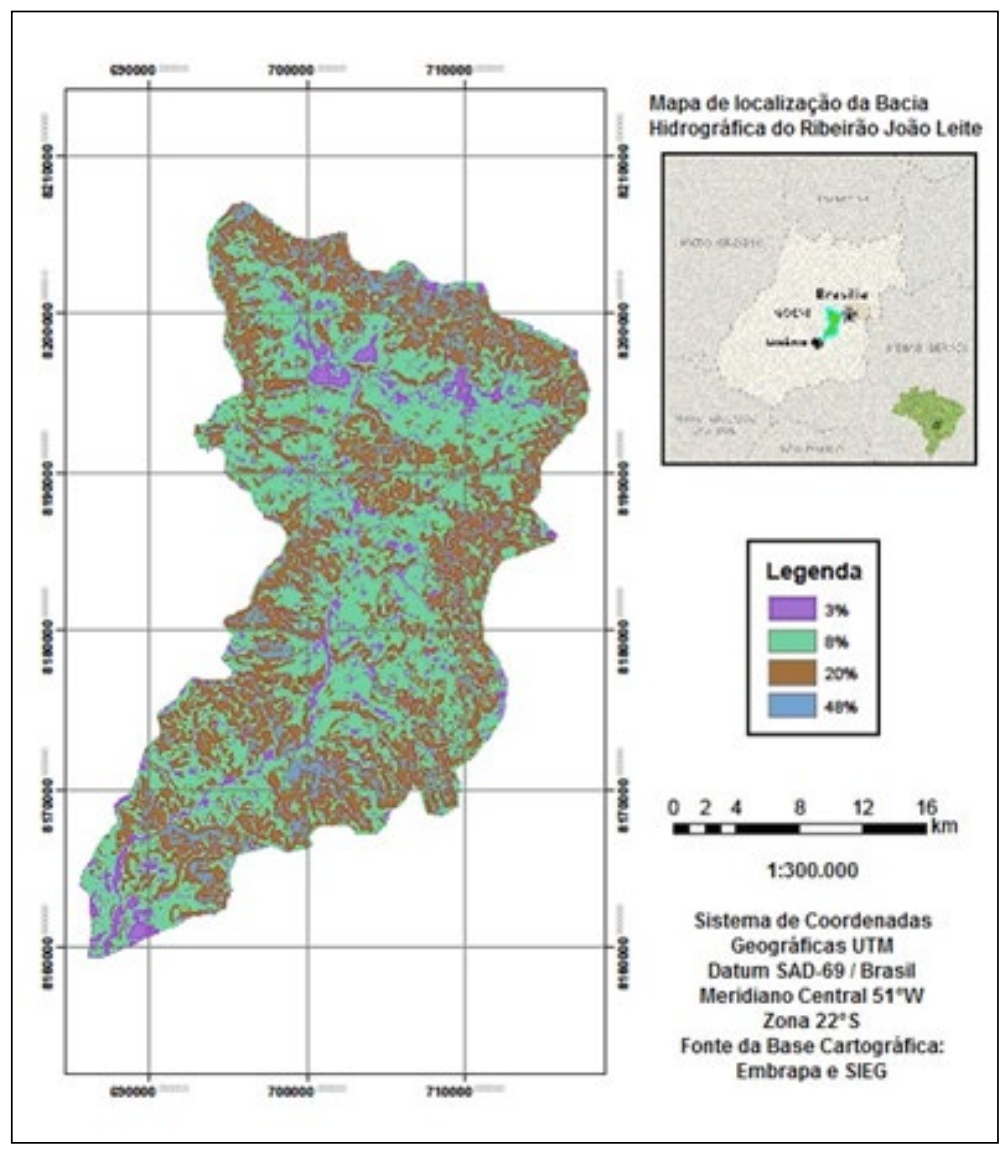

Fonte: Elaborado pelos autores. 


\subsubsection{Confecção do mapa de rampas homogêneas reclassificado ou em polígonos}

$\mathrm{Na}$ Figura 8 apresenta-se a combinação do mapa de declividade em porcentagem reclassificado, com o de aspecto reclassificado e posteriormente agrupado em polígonos, de onde foi extraído o mapa de diferença de altitude (DH) e $\alpha$ (Alfa).

Através dos polígonos é possível estabelecer as diferenças de altitudes encontradas na região de cada polígono gerado. Eles abrangem de forma mais homogênea as rampas existentes na bacia, tornando mais fácil a observação dos valores para estudo e utilização no software.

Figura 8 - Mapa de rampas homogêneas em polígonos (ou Mapa de rampas homogêneas reclassificado)

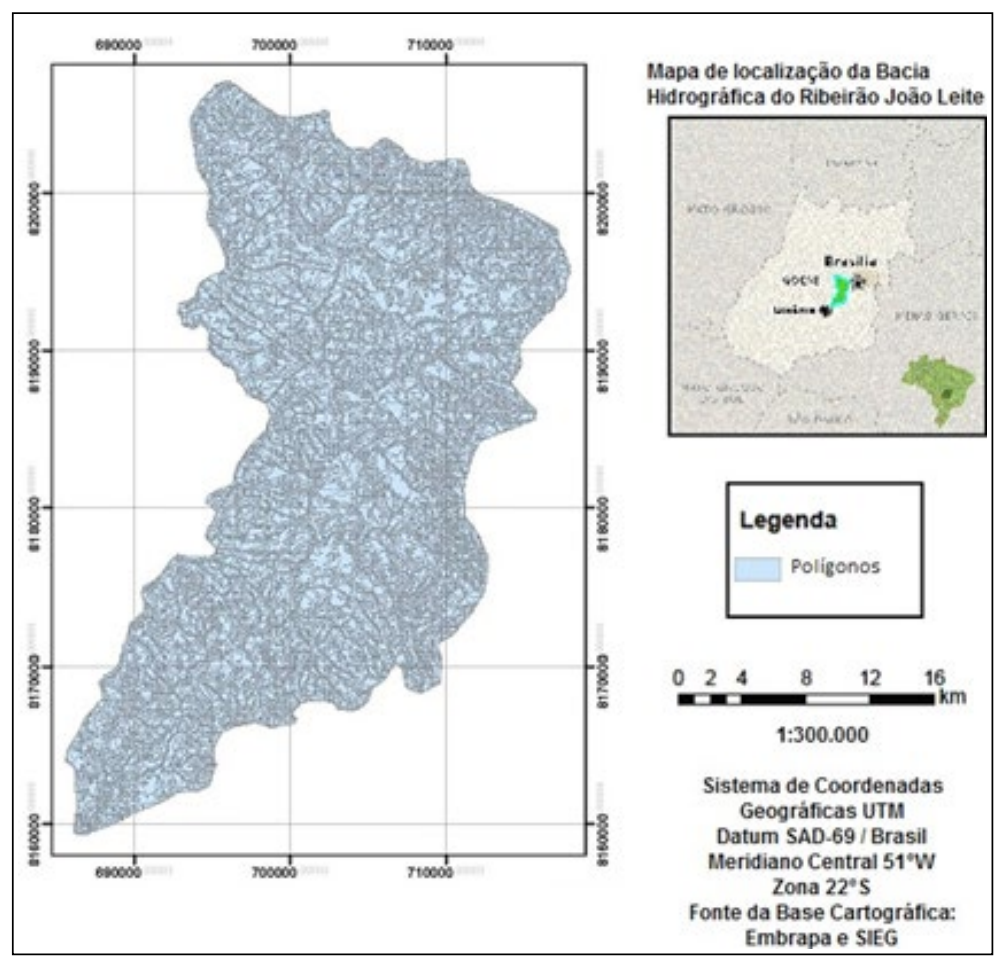

Fonte: Elaborado pelos autores.

\subsubsection{Confecção do mapa de diferença de altitude (DH)}

$\mathrm{Na}$ Figura 9 tem-se o mapa de diferença de altitude. 
Figura 9 - Mapa de diferença de altitude (DH), com valores em metros

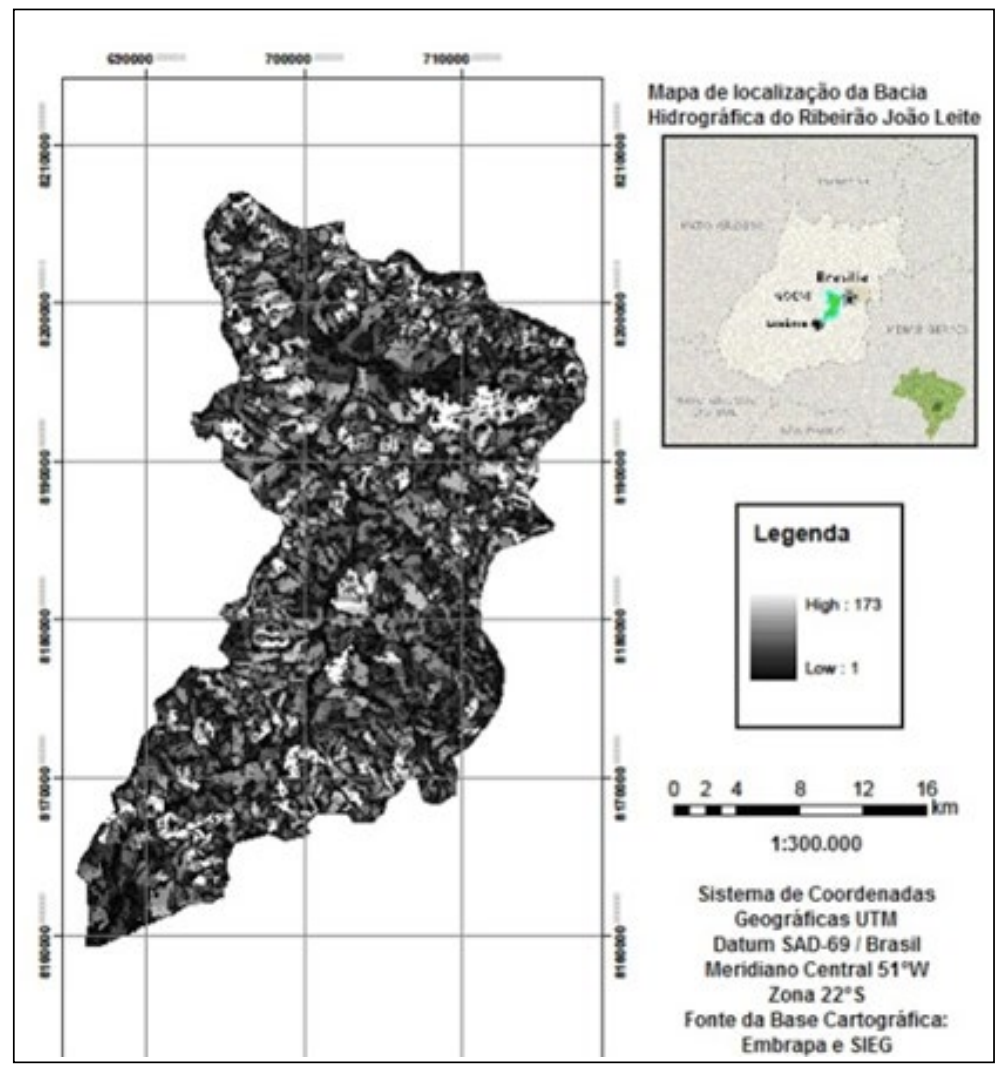

Fonte: Elaborado pelos autores.

\subsubsection{Confeç̧áo do mapa declividade média de rampa - graus $(\alpha)$}

O Mapa Declividade Média de Rampa é aperiantado nas Figuras 10 e 11 . A unidade de medidas utilizada nos valores é graus, sendo considerado o menor e maior grau de declividade encontrado na região da bacia. Utilizaram-se intervalos com média de $2^{\circ}$ para classificar o mapa. 
Figura 10 - Mapa de Declividade em Graus

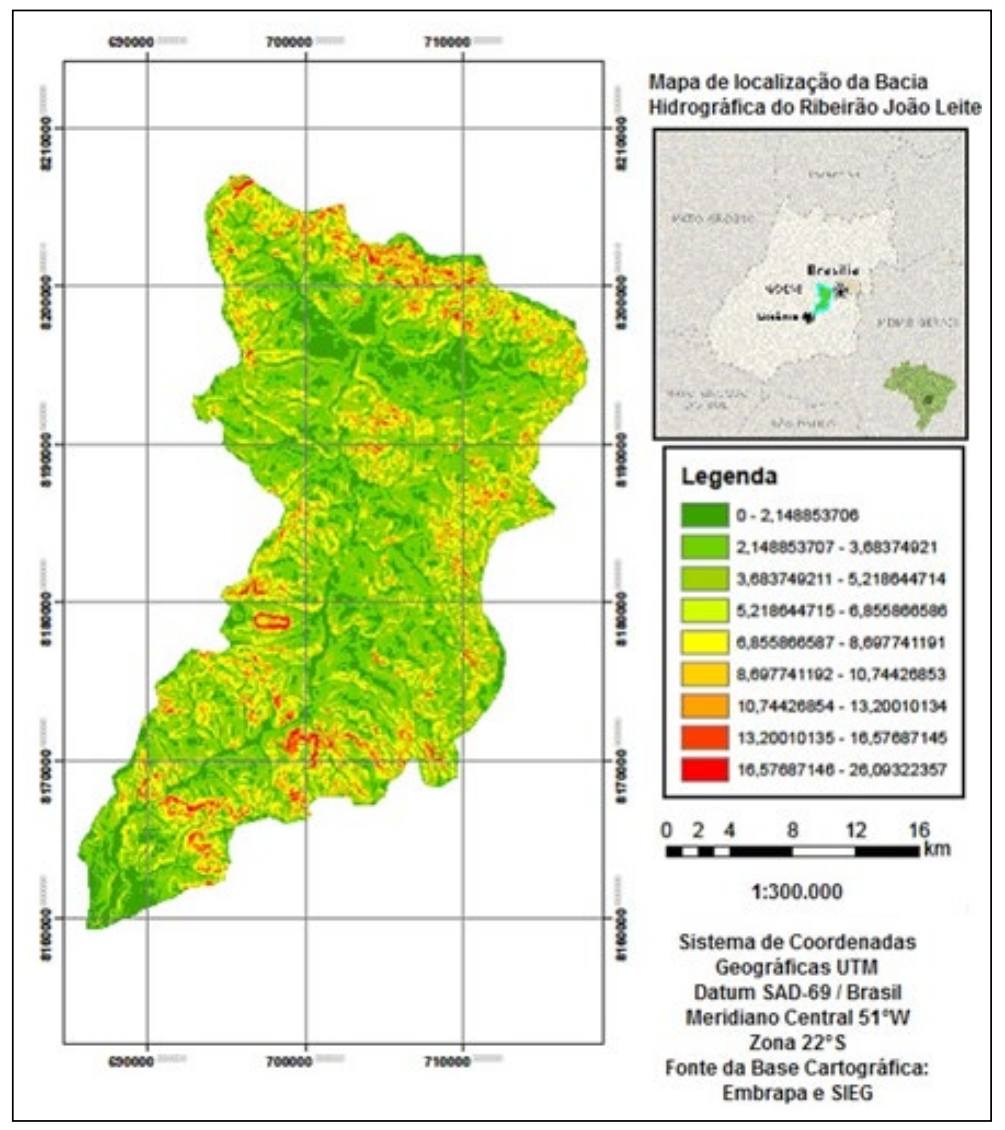

Fonte: Elaborado pelos autores. 
Figura 11 - Mapa da declividade média da rampa ( $\boldsymbol{\alpha}$ ) (em graus, considerando-se o menor e maior grau de declividade média encontrados na região da bacia)

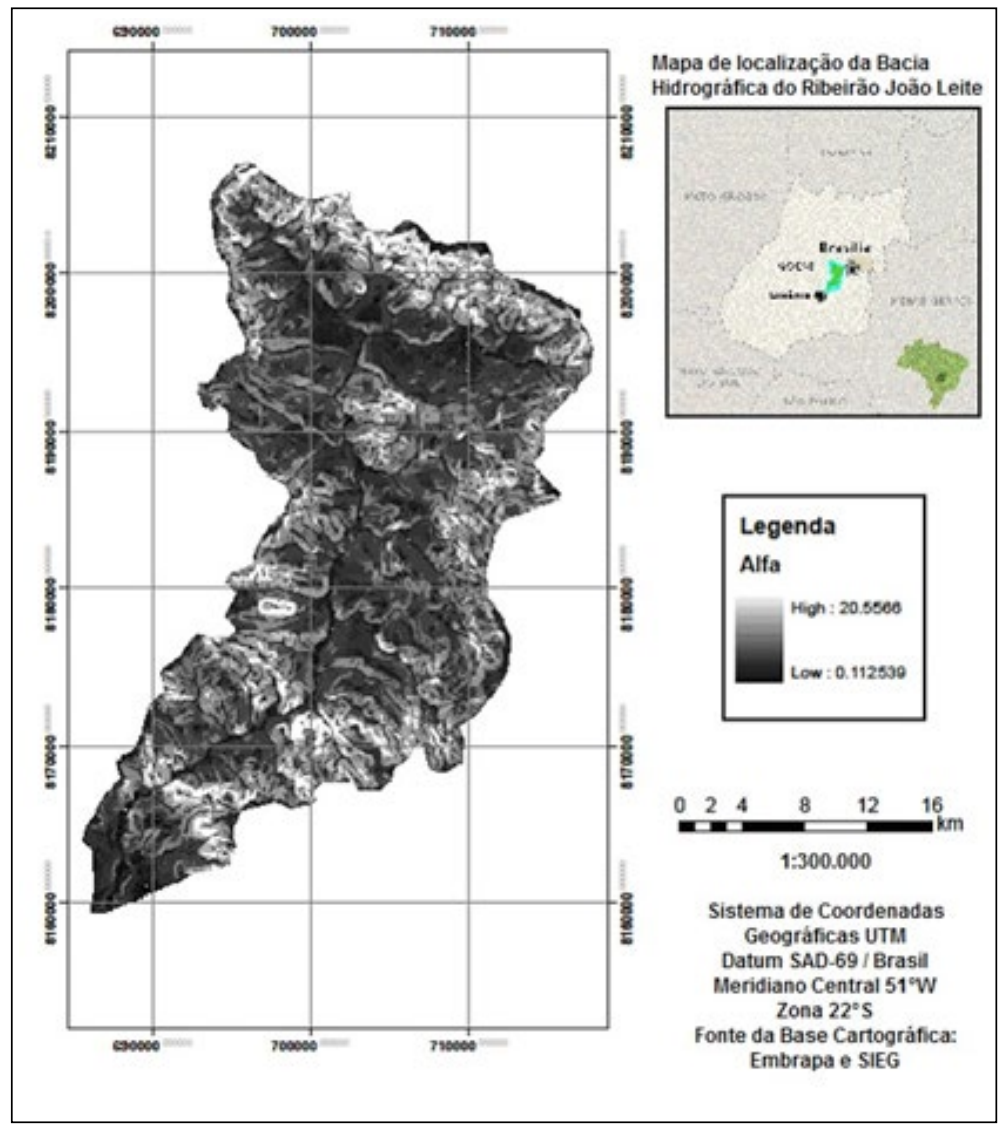

Fonte: Elaborado pelos autores.

\subsubsection{Confecçáo do mapa do fator de comprimento de rampa (L)}

O mapa do fator de comprimento de rampa (L) é apresentado na Figura 12. Na Tabela 8 mostram-se as áreas ocupadas pelas classes de comprimento de rampa em metros.

Tabela 8 - Área ocupada pelas classes de rampa (L)

\begin{tabular}{c|c|c}
\hline \multirow{2}{*}{ Comprimento de rampa $(\mathrm{m})$} & \multicolumn{2}{|c}{ Área } \\
\cline { 2 - 3 } & (ha) & $(\%)$ \\
\hline Menor que 200 & $30.507,68$ & 39,86 \\
\hline 200 a 500 & $24.373,55$ & 31,84 \\
\hline 500 a 1.000 & $14.937,86$ & 19,52 \\
\hline 1.000 a 1.500 & $5.016,17$ & 6,55 \\
\hline
\end{tabular}




\begin{tabular}{c|c|c}
\hline \multirow{2}{*}{ Comprimento de rampa $(\mathrm{m})$} & \multicolumn{2}{|c}{ Área } \\
\cline { 2 - 3 } & $(\mathrm{ha})$ & $(\%)$ \\
\hline Maior que 2.000 & $1.708,12$ & 2,23 \\
\hline Total & $76.543,38$ & 100,00 \\
\hline
\end{tabular}

Fonte: software ArcGis 9.3.

Figura 12 - Mapa de comprimento de rampa (metros, considerando-se o menor e maior comprimento de rampa encontrados na região da bacia)

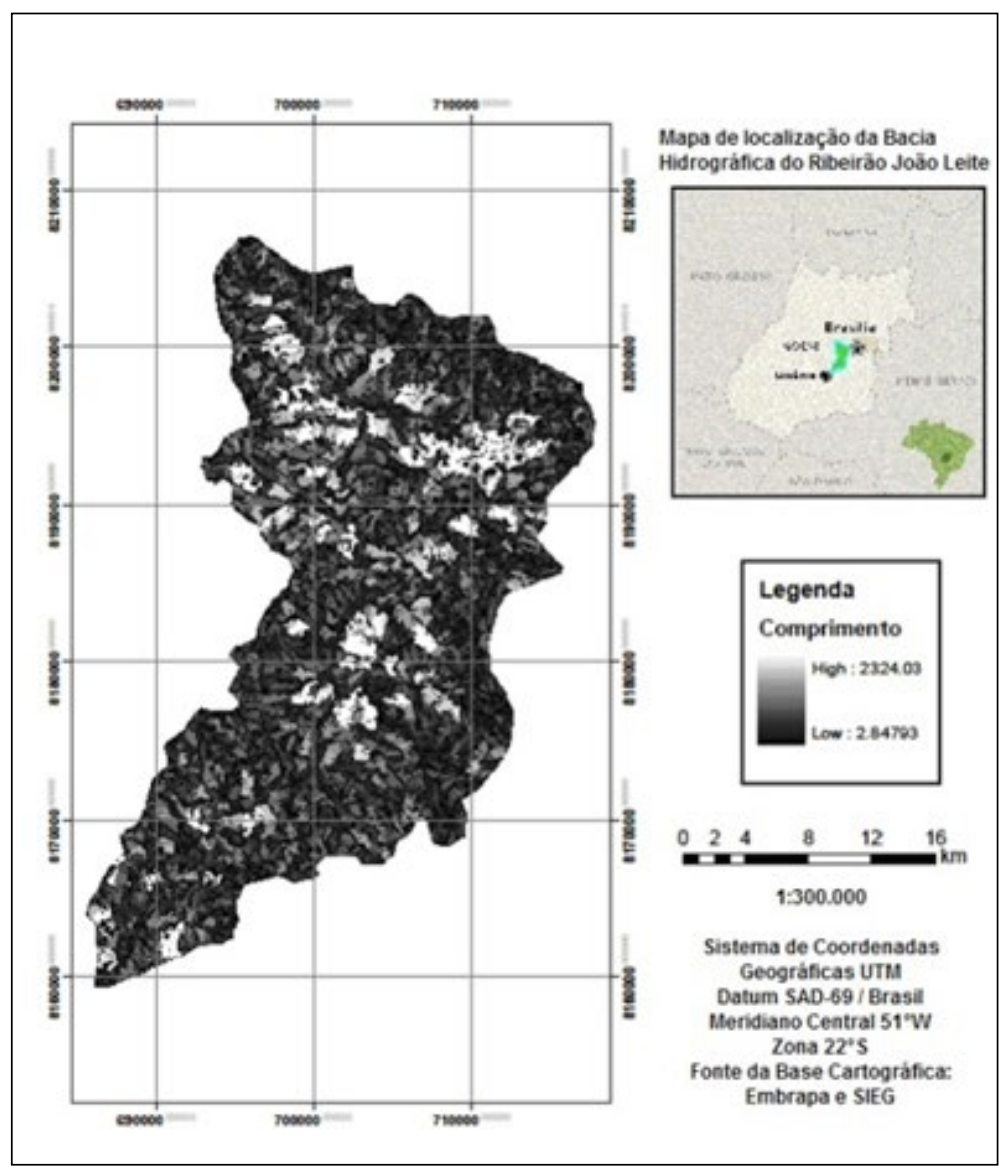

Fonte: Elaborado pelos autores.

\subsubsection{Cálculo do Fator Topográfico (LS)}

O mapa do Fator Topográfico é apresentado na Figura 13. Na Tabela 9 têm-se os valores para LS, apresentando a área ocupada pelas diferentes classes de fator topográfico estabelecido. 
Tabela 9 - Área ocupada pelas diferentes classes de fator topográfico (LS) em hectares e em termos percentuais

\begin{tabular}{c|c|c}
\hline \multirow{2}{*}{ Fator Topográfico } & \multicolumn{2}{|c}{ Área } \\
\cline { 2 - 3 } & (ha) & $(\%)$ \\
\hline Menor que 1 & $13.034,52$ & 17,03 \\
\hline 1 a 3 & $11.037,06$ & 14,42 \\
\hline 3 a 8 & $17.609,40$ & 23,01 \\
\hline 8 a 10 & $7.160,40$ & 9,35 \\
\hline Maior que 10 & $27.702,00$ & 36,19 \\
\hline Total & $76.543,38$ & 100,00 \\
\hline
\end{tabular}

Fonte: software ArcGis 9.3.

Figura 13 - Mapa do fator topográfico (LS) em hectares

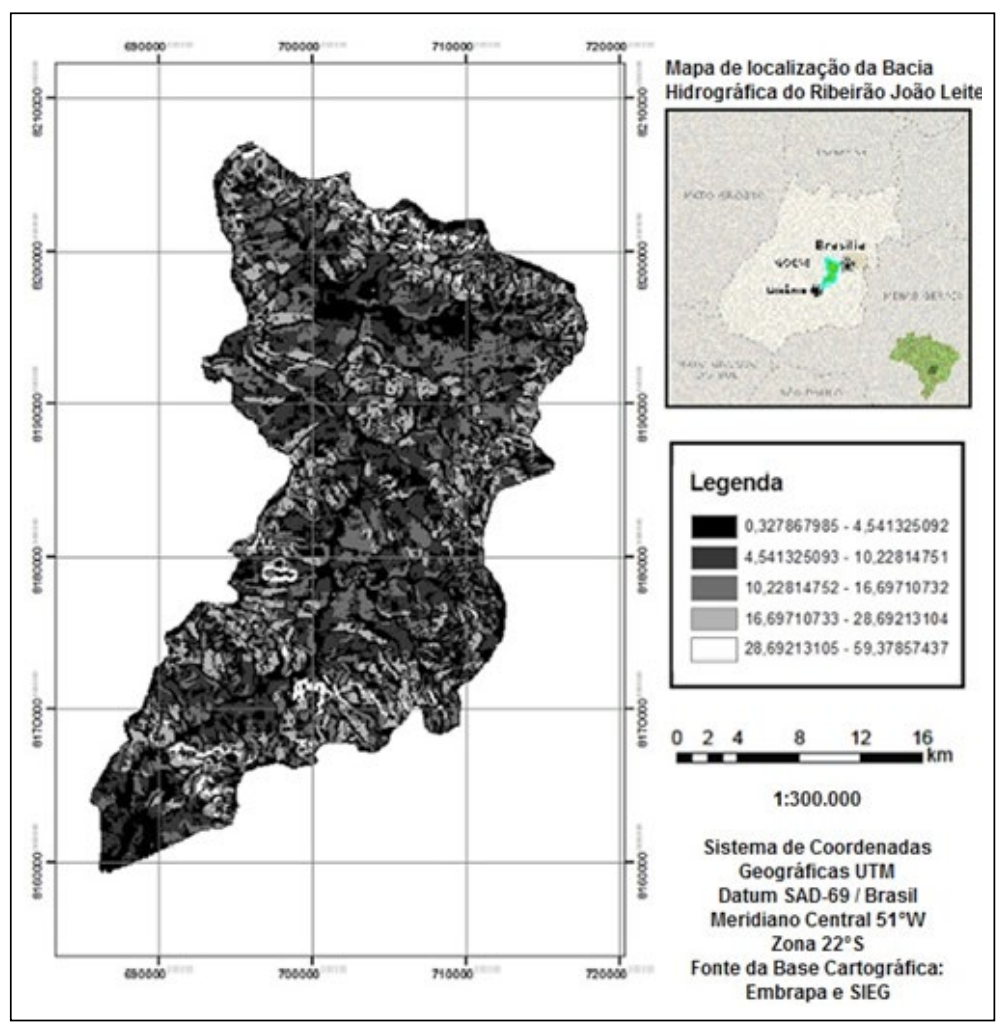

Fonte: Elaborado pelos autores.

$\mathrm{Na}$ Tabela 10 têm-se os valores para PNE das áreas ocupadas pelas categorias de potencial natural de erosão laminar. E na Figura 14 tem-se mapa do potencial de erosão laminar. Os valores de PNE encontrados na Tabela 10 mostram que o potencial natural 
de erosão laminar está classificado de moderado a fraco com predomínio da área da bacia de solo da classe Latossolos. Em pesquisas realizadas por Pasquatto e Tomazoni (2016), os pesquisadores relatam que os Latossolos são muito intemperizados e profundos, e devido a isso, possuem menor susceptibilidade a erosão.

Tabela 10 - Área ocupada pelas categorias de potencial natural de erosão laminar em (ton/ $\mathrm{km}^{2}$.ano)

\begin{tabular}{c|c|c|c}
\hline \multicolumn{2}{c|}{ PNE } & \multicolumn{2}{c}{ Área } \\
\hline Categoria & ton $/ \mathrm{km}^{2}$.ano & (ha) & $(\%)$ \\
\hline Fraco & Menor que 100 & $50.002,11$ & 65,33 \\
\hline Moderado & $100-300$ & $20.558,61$ & 26,86 \\
\hline Forte & Maior que 300 & $5.982,66$ & 7,81 \\
\hline & Total & $76.543,38$ & 100,00 \\
\hline
\end{tabular}

Fonte: software ArcGis 9.3

Figura 14 - Mapa do potencial natural à erosão laminar (PNE) ((ton/ $\mathrm{km}^{2}$.ano))

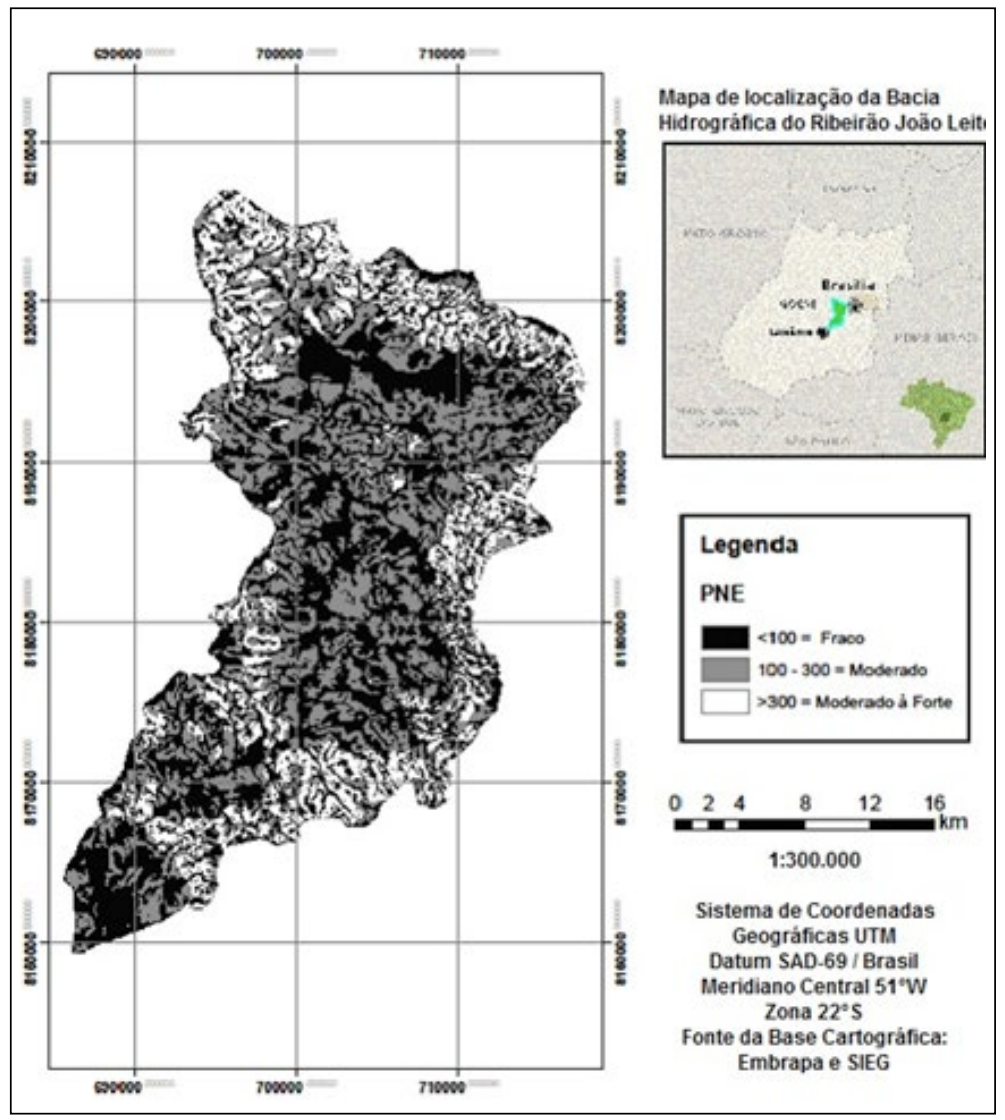

Fonte: Elaborado pelos autores. 


\subsubsection{Cálculo do mapa de perda de solos por erosão laminar (A) reclassificado}

O mapa de perda de solos por erosão laminar na Bacia Hidrográfica do Ribeirão João Leite na Figura 15 está reclassificado em 5 (cinco) classes assim como na Tabela $1^{*} 1$. Os valores atribuídos para A (Tabela 11), em cada classe estabelecida, foram obtidos de Wischmeier e Smith (1958).

Conforme a Tabela 11 e no mapa de perda de solos por erosão laminar na Bacia Hidrográfica do Ribeirão João Leite foi constatada que, da área total da bacia, 47,30\% possui perdas por erosão laminar menor que 1 (uma) ton $/ \mathrm{km}^{2}$ ao ano (risco muito baixo), $26,71 \%$ estão entre 1 e 5 ton $/ \mathrm{km}^{2}$ ao ano (baixo risco). Entre 5 e 10 ton $/ \mathrm{km}^{2}$ ao ano, $15,99 \%$ da área da bacia, representando risco médio. A área com alto risco corresponde a $7,43 \%$, enquadrando-se no intervalo de perda de 10 a 20 ton $/ \mathrm{km}^{2}$ ao ano. E 2,57\% da área possui alto risco de erosão laminar, com perdas superiores a $20 \mathrm{ton} / \mathrm{km}^{2}$ ao ano. O potencial moderado à erosão laminar é de $15,99 \%$ da área total da bacia, conforme Tabela 11, onde as áreas degradadas e ocupadas por agricultura são mais críticas por propiciar a perda laminar de solos e devem ser atendidas prioritariamente com técnicas conservacionistas. Tal afirmação é reforçada pelo mapa de uso do solo e cobertura vegetal natural, onde apresenta $63,67 \%$ do uso do solo com a agricultura tanto na montante quanto na jusante da bacia. As áreas mais críticas de perda de solos (10\%, com potencial de risco alto ou muito alto) estão associadas às elevadas declividades principalmente no sul da bacia, a elevados comprimentos de rampa nas nascentes da bacia e as áreas ocupadas por agricultura.

As áreas que ocorreram a maior perda de solos por erosão laminar estão localizadas nas nascentes da bacia e as que ocorreram menor perda de solos por erosão laminar está localizado no centro da bacia, resultado que está intimamente relacionado ao mapa do fator topográfico, por declividades e comprimento de rampas elevadas. Resultados similares foram encontrados por Pereira et al. (2015) na bacia do Córrego Cascavel no estado de Goiás.

Contudo, vale ressaltar que em função das limitações da EUPS, os resultados devem ser validados com estudos experimentais, servindo no momento como indicativo ambiental.

Tabela 11 - Área ocupada pelas classes de perda de solos por erosão laminar (ton $/ \mathrm{km}^{2}$.ano)

\begin{tabular}{c|c|c|c}
\hline \multirow{2}{*}{ Categoria } & \multirow{2}{*}{ ton $/ \mathrm{km}^{2}$.ano } & \multicolumn{2}{|c}{ Área } \\
\cline { 3 - 4 } & & (ha) & $(\%)$ \\
\hline Muito baixo & Menor que 1 & $36.205,54$ & 47,30 \\
\hline Baixo & $1-5$ & $20.442,13$ & 26,71 \\
\hline Médio & $5-10$ & $12.236,02$ & 15,99 \\
\hline Alto & $10-20$ & $5.689,60$ & 7,43 \\
\hline Muito alto & Maior que 20 & $1.970,09$ & 2,57 \\
\hline
\end{tabular}

Fonte: Wischmeier e Smith (1958). 
Figura 15 - Mapa de perda de solos por erosão laminar na Bacia Hidrográfica do Ribeirão João Leite (ton $/ \mathrm{km}^{2}$.ano)

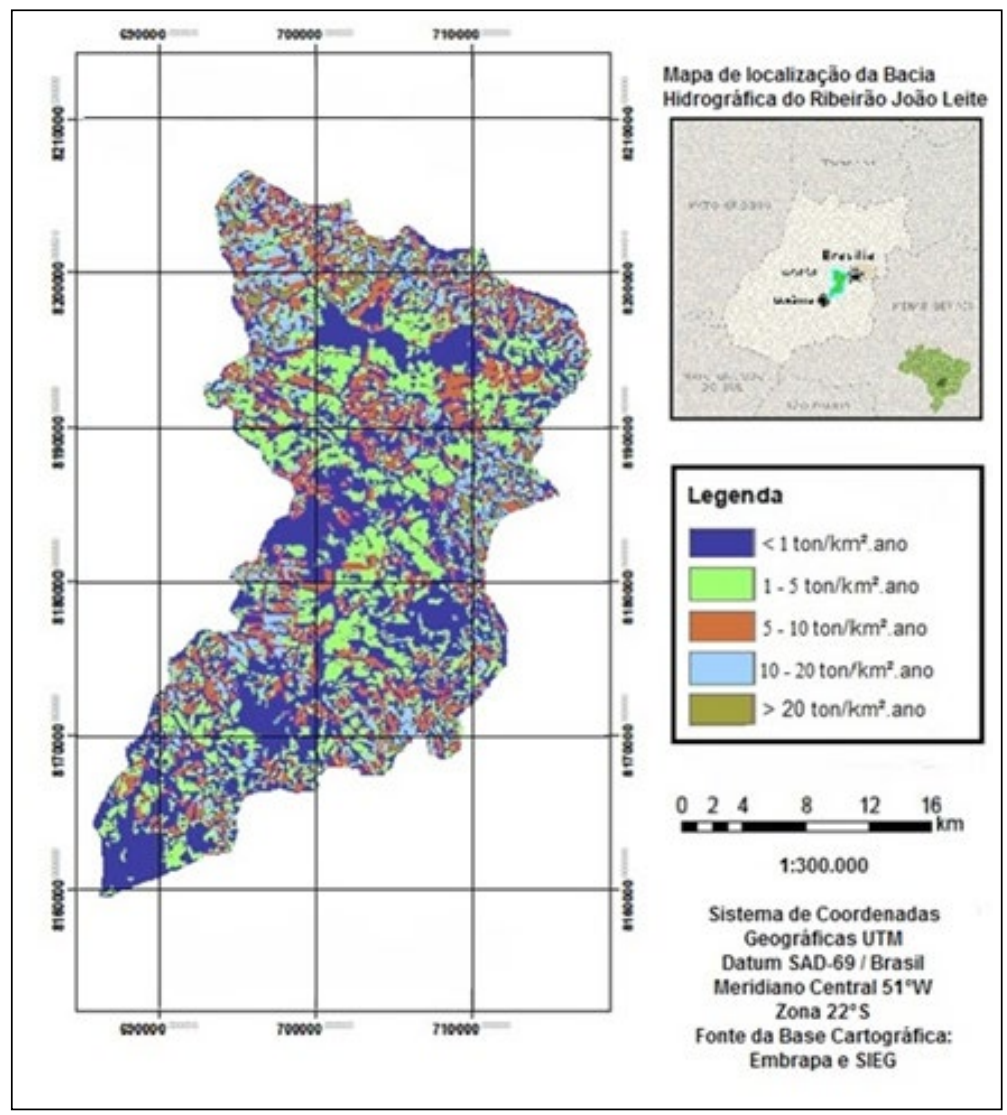

Fonte: Elaborado pelos autores.

\section{CONCLUSÃO}

O presente trabalho teve por objetivo estimar a perda de solos por erosão laminar na bacia hidrográfica do Ribeirão João leite onde, constatou-se que a classe de ocorrência do PNE ao longo da bacia é possui um potencial natural de erosáo de fraco a moderado evidenciado na tabela 10, aproximadamente de $100-300$ ton $/ \mathrm{km}^{2}$.ano. O valor estimado para o fator de erobilidade varia de 0,016-0,33 t.h/(MJ.mm) e os valores de erosividade com uma média anual de 72,47 ton $/ \mathrm{km}^{2}$.ano.

A equação universal de perdas de solos juntamente com o uso do sistema de informaçóes geográficas possibilitou avaliar a perda de solos na bacia hidrográfica do Ribeirão João Leite, fornecendo assim, parâmetros para a elaboração de um planejamento conservacionista. A Equação Universal de Perda de Solos se mostrou uma equação importante no processo de integração dos dados de perdas de solos por erosão laminar, principalmente pela facilidade de cálculo com a inclusão de um algoritmo para o cálculo 
automatizado dos fatores topográfico, de potencial natural à erosão laminar, de perda de solo por erosão laminar, e comprimento de rampa. O sistema de informaçôes geográficas se mostrou altamente eficiente no sentido de possibilitar a obtenção de informaçôes macros de forma rápida.

Por meio da análise dos resultados obtidos, observou-se que a área da bacia, apresenta menor incidência de áreas com alto potencial à erosão laminar, o que diminui o impacto da perda de solos superficiais na região da bacia. Existe maior predominância das áreas com baixo potencial $(74,01 \%$ da área total da bacia) náo comprometendo, assim, a sustentabilidade dos recursos naturais da bacia.

Em função do resultado do mapa de perdas de solos por erosão laminar na Bacia do Ribeirão João Leite, recomenda-se um planejamento de medidas preventivas como práticas conservacionistas e fiscalizaçáo do uso do solo na bacia, pois mais de 25,99\% (conforme dados da Tabela 11, onde considerou-se a soma da área ocupada pelas classes de perda de solos por erosáo laminar em termos percentuais) da bacia possui índice de potencial a erosão laminar de moderado a alto assim como adotado por Pereira et al. (2015) na Bacia Hidrográfica do Córrego Cascavel em Goiás. O comportamento de perdas de solo tanto na bacia do Cascavel quanto ao do Ribeirão João Leite em relação à série temporal é de constante degradaçáo devido à expansão urbana e agrícola, caracterizando uma exponencial crescente do processo de aceleração da erosão.

\section{REFERÊNCIAS}

BARBOSA, R. S; LIMA, C. V. Análise Sedimentométrica da Média e Baixa Bacia do Ribeirão João Leite/GO. VI SIMPÓSIO NACIONAL DE GEOMORFOLOGIA. Goiânia, 2006. Anais... Goiânia, 2006.

BAPTISTA, G.M.M. Diagnóstico Ambiental da Perda Laminar de Solos por Meio do Geoprocessamento. 1997. 112p. Dissertação (Mestrado) - Departamento de Engenharia Civil, Universidade de Brasília, Brasília, 1997.

BERTONI, J.; LOMBARDI NETO, F. Conservação do solo. São Paulo: Ícone, 1990.

CAMARGO, L.A. Mineralogia da Argila e Atributos Físicos de um Argissolo em Curvaturas de Relevo. 2009. 128p. Dissertação (Mestrado) - Faculdade de Ciências Agrárias e Veterinárias, Universidade Estadual Paulista, Jaboticabal, 2009.

CEMIN, G.; PÉRICO, E; SCHNEIDER, V. E.; FINOTTI, A. R. Determinação da perda de solos por erosão laminar na bacia hidrográfica do arroio Marrecas, RS, Brasil. Scientia Plena, v. 9, n. 1, p. 1-9, 2013.

DENARDIN, J. E. Erodibilidade de Solo Estimada por Meio de Parâmetros Físicos e Químicos. 1990. 81p. Tese (Doutorado) - Escola Superior de Agricultura "Luiz de Queiroz", Universidade de São Paulo, Piracicaba, 1990. 
DURÃES, M. F.; MELLO, C. R. Distribuição espacial da erosão potencial e atual do solo na Bacia Hidrográfica do Rio Sapucaí, MG. Eng Sanit Ambient. v. 21 n. 4, p. 677-685, 2016.

EMPRESA BRASILEIRA DE PESQUISA AGROPECUÁRIA (EMBRAPA). 2005. Imagem do radar SRTM folha SE-22-X-B. Disponível em: www.relevobr.cnpm.embrapa. br. Acessado em: 07 dez. 2016.

GOIÁS. Decreto No 5.704, DE 27 DE DEZEMBRO DE 2002. Cria a Área de Proteção Ambiental (APA) João Leite e dá outras providências. Diário Oficial, 2002.

GRISMER, Mark E. Standards vary in studies using rainfall simulators to evaluate erosion. California Agriculture, v. 66, n. 3, p. 102-107, 2012.

INSTITUTO DE DESENVOLVIMENTO TECNOLÓGICO DO CENTRO OESTE. Zoneamento Ecológico-Econômico do Município de Goiânia. Goiânia: Prefeitura Municipal de Goiânia, 2008.

LEVY, M.C.T.C. Avaliação dos cenários da produção agrícola visando a sustentabilidade do uso das Terras de Piracicaba (SP). 1995. 104p. Dissertação (Mestrado em Solo e Nutrição de Plantas) - Escola Superior de Agricultura "Luiz de Queiroz", Universidade de São Paulo, Piracicaba, 1995.

LEZONIER, L. S.; BERTOLDI, L.; SANTOS, A. T.; MARTINOTTO, T. T. Estimativa da Erosão Bruta no Município de São Miguel do Oeste, SC. Unoesc \& Ciência - ACET Joaçaba, v. 7, n. 2, p. 177-186, 2016.

MACHADO, P. J. O. (Org.). Diagnóstico físico-ambiental da Bacia Hidrográfica do Córrego São Pedro: um exercício acadêmico de gestáo dos recursos hídricos. Ubá: Ed. Geographica, 2010.

MOURA, M. M.; FONTES, C.S.; SANTOS, M. H.; ARAUJO FILHO, R.N.; HOLANDA, F.S.R. Estimativa de Perda de Solo no Baixo São Francisco Sergipano.

Revista Scientia Agraria. SA v. 18, n 2, p.126-135, 2017.

NUNES, M. C. M.; NEVES, S.M. A. S.; NEVES, R.J.; KREITLOW, J. P.; CHIMELLO, A. M. Susceptibility To Water Erosion Of Soils From The Municipality Salto do Céu, SW Mato Grosso State, Brazil - Brasil. Geografia, v. 38, p. 191-206, 2013.

OLIVEIRA, A. H.; SILVA, M. A.; SILVA, M. L. N.; CURI, N.; KLINKE NETO, G.; FREITAS, D.A.F. Development of Topographic Factor Modeling for Application in Soil Erosion Models. Soil Processes and Current Trends in Quality Assessment Chapter 4. InTech. p. 111-138, 2013. 
PASQUATTO, M. C.; TOMAZONI, J. C. Estudo do processo erosivo laminar na bacia de captação do rio Barro Preto, em Coronel Vivida - PR. Revista Brasileira de Geografia Física, v. 9, n. 2, p. 555-570, 2016.

PEREIRA, T.S.R.; SANTOS, K. A.; SILVA, B. F.; FORMIGA, K. T. M. Determinação e Espacialização da Perda de Solo da Bacia Hidrográfica do Córrego Cascavel, Goiás. Rev. Geogr. Acadêmica, v. 9, n. 2, p. 76-93, 2015.

ROCHA, J. V.; LOMBARDI NETO, F.; BACELAR, A. A. A. Metodologia para determinação do fator comprimento de rampa (L) para a equação universal de perda de solo. In: SIMPÓSIO DE USUÁRIOS DE IDRISI. Anais.... Campinas: UNICAMP/ FAMCG, 1995. p. 3-6.

RORIZ, J.O. S.; AOKI, A. I.; SOUZA, L. C. D.; AVELINO, M.C.G. S.; FONZAR, G.M.B. Uso da Equação USLE em SIG na Identificação e Quantificação de Erosão Laminar. Rev. Conexão Eletrônica v. 13, n. 1, 2016.

SANTOS, S.A. Análise de suscetibilidade e potencial à erosão laminar da Área de Preservação Ambiental das Nascentes do Rio Vermelho. XVII SIMPÓSIO BRASILEIRO DE SENSORIAMENTO REMOTO - SBSR, João Pessoa-PB, Brasil, 25 a 29 de abril de 2015, INPE. p. 7246-7251. Anais... João Pessoa-PB, Brasil.

SILVA, L. C. N.; LUCHIARI, A. Estimativa de Perda de Solos por Erosão Laminar na Bacia Hidrográfica do Córrego Baguaçu-SP. Revista do Departamento de Geografia, v. 32 , p. 15-28, 2016.

\section{SISTEMA ESTADUAL DE ESTATÍSTICA E INFORMAÇÕES GEOGRÁFICA}

DE GOIÁS (SIEG). 2010. Mapas de tipos de solos, de uso da terra e cobertura vegetal natural, da bacia hidrográfica do Ribeirão João Leite. Disponível em: <www.sieg.go.gov. br>. Acessado em: 07 dez. 2016.

SOUZA, L. A.; SOBREIRA, F.G. A Avaliação da Geração de Sedimentos ao Longo da Bacia Hidrográfica do Ribeirão Carmo. Potencial Natural de Erosão, Feições Morfológicas e Cicatrizes de Movimentos de Massa. São Paulo, UNESP, Geociências, v. 36, n. 2, p. $285-299,2017$.

STEIN, D. P.; DONZELLI, P. L.; GIMENEZ, A. F. PONÇANO, W. L. LOMBARDI NETO, F. Potencial de erosão laminar, natural e antrópico na Bacia do PeixeParanapanema. IV SIMPÓSIO NACIONAL DE CONTROLE DE EROSÃO. Marília, SP, 1987. p. 105-135. Anais... Marília, SP, 1987.

WISCHMEIER, W.H.; SMITH, D.D. Predicting rainfall erosion losses from cropland east of the Rocky Mountains: guide selection of practices for soil and water conservation. U.S.A.: Washington, DC.: USDA, 1958. 58p. 